IZA DP No. 9348

The Impact of Syrian Refugees on Natives'

Labor Market Outcomes in Turkey:

Evidence from a Quasi-Experimental Design

Evren Ceritoglu

H. Burcu Gurcihan Yunculer

Huzeyfe Torun

Semih Tumen

September 2015 


\title{
The Impact of Syrian Refugees on Natives' Labor Market Outcomes in Turkey: Evidence from a Quasi-Experimental Design
}

\author{
Evren Ceritoglu \\ Central Bank of the Republic of Turkey \\ H. Burcu Gurcihan Yunculer \\ Central Bank of the Republic of Turkey \\ Huzeyfe Torun \\ Central Bank of the Republic of Turkey \\ Semih Tumen \\ Central Bank of the Republic of Turkey and IZA
}

Discussion Paper No. 9348

September 2015

\author{
IZA \\ P.O. Box 7240 \\ 53072 Bonn \\ Germany \\ Phone: +49-228-3894-0 \\ Fax: +49-228-3894-180 \\ E-mail: iza@iza.org
}

\begin{abstract}
Any opinions expressed here are those of the author(s) and not those of IZA. Research published in this series may include views on policy, but the institute itself takes no institutional policy positions. The IZA research network is committed to the IZA Guiding Principles of Research Integrity.

The Institute for the Study of Labor (IZA) in Bonn is a local and virtual international research center and a place of communication between science, politics and business. IZA is an independent nonprofit organization supported by Deutsche Post Foundation. The center is associated with the University of Bonn and offers a stimulating research environment through its international network, workshops and conferences, data service, project support, research visits and doctoral program. IZA engages in (i) original and internationally competitive research in all fields of labor economics, (ii) development of policy concepts, and (iii) dissemination of research results and concepts to the interested public.
\end{abstract}

IZA Discussion Papers often represent preliminary work and are circulated to encourage discussion. Citation of such a paper should account for its provisional character. A revised version may be available directly from the author. 
IZA Discussion Paper No. 9348

September 2015

\section{ABSTRACT \\ The Impact of Syrian Refugees on Natives' Labor Market Outcomes in Turkey: Evidence from a Quasi-Experimental Design*}

Civil war in Syria, which started in March 2011, has led to a massive wave of forced immigration from the Northern Syria to the Southeastern regions of Turkey. This paper exploits this natural experiment to estimate the impact of Syrian refugees on the labor market outcomes of natives in Turkey. Using a difference-in-differences strategy, we find that immigration has considerably affected the employment outcomes of natives, while its impact on wage outcomes has been negligible. We document notable employment losses among informal workers as a consequence of refugee inflows. The majority of those who lost their informal jobs have either left the labor force or remained unemployed. Overall, unemployment rates have increased, while labor force participation, informal employment, and job finding rates have declined among natives. Disadvantaged groups - i.e., females, younger workers, and less-educated workers - have been affected the worst. The prevalence of informal employment in the Turkish labor markets has amplified the negative impact of Syrian refugee inflows on natives' labor market outcomes.

JEL Classification: J15, J21, J46, J61, C21

Keywords: Syrian civil war, immigration, Turkey, labor market, informality, difference in differences

Corresponding author:

Semih Tumen

Research and Monetary Policy Department

Central Bank of the Republic of Turkey

Istiklal Cad. No:10

06100 Ulus, Ankara

Turkey

E-mail: semih.tumen@tcmb.gov.tr

\footnotetext{
* We thank Altan Aldan, seminar participants at the Central Bank of the Republic of Turkey, and the participants of the 2015 IZA/CEPR European Summer Symposium in Labour Economics in Buch/ Ammersee for useful comments. We are particularly grateful to Albrecht Glitz (the editor) and two anonymous referees for extremely helpful suggestions. The views expressed here are of our own and do not necessarily reflect those of the Central Bank of the Republic of Turkey. All errors are ours.
} 


\section{Introduction}

The Syrian Civil War, which began in the Spring of 2011, has displaced millions of Syrians. Based on the United Nations (UN) figures, around 3.6 million Syrian refugees have fled to the neighboring countries. Turkey alone has received more than 1.6 million Syrian refugees as of the end of 2014. These refugees are spread around Southeastern Turkey and are particularly located in the cities with refugee camps constructed and controlled by the Turkish government. The refugees do not have a formal work permit; however, they can still affect the labor market outcomes of natives living in the area, since they supply inexpensive informal unskilled labor. The main goal of this paper is to use this forced immigration as a natural experiment to analyze the effect of Syrian immigrants on the labor market outcomes of natives.

Investigating the impact of immigration on the labor market outcomes of natives is a longstanding matter of interest. The textbook model suggests that immigration leads to an outward shift in the labor supply curve. Although immigration may also cause an outward shift in labor demand, the combination of increased labor supply and demand due to immigration likely yields excess supply in the labor market. During this process, part of the natives in employment are replaced by immigrants. As a result, the equilibrium wages and employment rates for natives are expected to fall. This simplest theoretical framework suggests that immigrants have a negative impact on the labor market outcomes of natives.

The empirical literature, however, reports mixed results. The early literature typically argues that immigration has only negligible effects on the labor market outcomes of natives. ${ }^{1}$ Several studies, including Altonji and Card (1991) and Goldin (1994), have exploited the variation in the number of immigrants across regions and time in the United States to analyze the impact of immigration on natives' wages and employment. Pischke and Velling (1997) perform a similar analysis with German data. They consistently find that immigrants have only a small effect on natives' labor market outcomes. One explanation is that immigrant workers are poor substitutes, at least in the short run, for native workers, because the human capital stocks of immigrants are not immediately transferable to the host economy. Thus, if there exists any

\footnotetext{
${ }^{1}$ See Borjas (1994), Friedberg and Hunt (1995), and LaLonde and Topel (1997) for detailed reviews of this early literature.
} 
effect of immigrants on the labor market outcomes of natives, it can only appear in the long run. $^{2}$

The early literature has been criticized by Borjas, Freeman, and Katz (1996) on the basis of the idea that immigrant flows to a certain area can potentially generate several secondorder effects such as movements of capital, outflows of natives, and changes in the patterns of inter-city trade. This criticism suggests that immigrants are perhaps better substitutes for natives than the early studies suggest. Based on this conjecture, the more recent literature adopts a production-function approach, in which the immigrant and native workers are two substitutable inputs. In contrast to the early literature, studies adopting this methodology report more sizable effects of immigration on the labor market outcomes of the natives. ${ }^{3}$

Although they claim different results, the common feature of these two literatures is that they rely on non-experimental data from advanced countries, mostly the United States-i.e., long-term census data reflecting a more general co-evolution of the immigrant and native populations. The most well-known problem with non-experimental data is that immigration is generally voluntary and, therefore, appropriate techniques are necessary to address the selection bias. The literatures cited above typically rely on selection correction techniques à la Borjas $(1987,1991)$ and the related instrumental variable methods. There is a distinct line of research relying on quasi-experimental techniques to estimate the impact of immigration on the labor market outcomes of the natives. This literature typically exploits an involuntary influx of a massive immigrant population - due to civil war and other political factors - to estimate the causal effect of interest without relying on the classical selection-correction methods. Major papers in this literature include Card (1990), Hunt (1992), Carrington and de Lima (1996), Friedberg (2001), Mansour (2010), and Glitz (2012). ${ }^{4}$ With a few exceptions, the quasiexperimental evidence does not point out a significant impact of immigration on natives' outcomes.

\footnotetext{
${ }^{2}$ See, e.g., Friedberg (2000), Weiss, Sauer, and Gotlibovski (2003), and Cohen-Goldner and Paserman (2011).

${ }^{3}$ See, e.g., Card (2001), Borjas (2003), Angrist and Kugler (2003), Borjas and Katz (2007), Card (2009), and Ottaviano and Peri (2011).

${ }^{4}$ See also Aydemir and Kirdar (2013) and Maystadt and Verwimp (2014).
} 
Our quasi-experimental design exploits the forced inflow of refugees from Northern Syria to the Southeastern regions of Turkey. We employ the following difference-in-differences strategy to estimate the impact of refugee inflows on the labor market outcomes of natives. Massive inflows of Syrian refugees to Turkey have started at the beginning of 2012. So, the date of treatment is assumed to be January 1st, 2012. We set a symmetric window around this date: 2010-2011 and 2012-2013 are set as pre-immigration and post-immigration periods, respectively. Although a tiny fraction of the Syrian refugees may have left Southeastern Turkey and moved toward the Northern and Western parts of the country, a very large portion of the refugees have been located in the cities nearby Turkey-Syria border. Using the official figures published by Turkish Disaster and Emergency Management Presidency (AFAD), we construct a "treatment area" from the cities in the Southeastern part of Turkey, for which the refugeepopulation ratio is above 2 percent. The rest of the cities in the neighboring regions that are hosting only negligible amounts of Syrian refugees form the "control area," which is similar to the "treatment area" in terms of cultural aspects, socio-demographic characteristics, and the level of economic development. ${ }^{5}$ The data set includes only the natives-i.e., we do not observe any details for the refugees. ${ }^{6}$ Given the data on natives, our difference-in-differences strategy identifies the impact of Syrian refugees on the labor market outcomes of the natives living in the treatment area, based on a pre- vs post-immigration comparison with the control area.

We find that Syrian refugee inflows have negatively affected the likelihood of employment for natives, while their wage outcomes have not been affected in a statistically significant way. We focus on four mutually exclusive labor market outcomes defined in terms of their ratios to the population of native workers of age 15-64: $(i)$ not in labor force, $(i i)$ formal employment, (iii) informal employment, and (iv) unemployment. We find that the informal employment-

\footnotetext{
${ }^{5}$ Our empirical design is similar to various other studies attempting to identify the causal effect of interest by using data on neighboring regions. For example, Card and Krueger (1994) investigate the impact of a change in the minimum wage law in New Jersey on employment outcomes by performing a comparison across the fast food restaurants among New Jersey and Eastern Pennsylvania. The main identifying assumption is that the two regions are similar in many respects. Another example is Lavy (2010) who exploits regional proximity within Israel to identify the effect of a program allowing for free choice among public schools. We believe that the similarities between our control and treatment areas along several dimensions allow us to perform a difference-in-differences exercise.

${ }^{6}$ We use the Turkish Household Labor Force survey in our analysis. The sampling strategy of this survey is based on the "addressed-based population registration system," which targets the non-institutional civilian population only. Thus, refugees are not included into the sample. See Section 3 for further details on the data set and restrictions.
} 
to-population ratio has declined by around 2.2 percentage points as a consequence of refugee inflows. Of this decline in informal employment, around 50 percent went out of the labor force, 32 percent remained unemployed, and 18 percent switched to a formal job. For males, the decline in the informal employment-to-population ratio is 1.9 percentage points. Most of the males who lost their informal jobs remained unemployed. For females, however, the decline is much higher, 2.6 percentage points. Almost all of the females who lost their informal jobs went out of the labor force. These findings suggest that native workers who lost their informal jobs were substituted by informal Syrian refugees. Among these substituted natives, females have found it extremely difficult to find new jobs and, consequently, dropped out of the workforce. Males, on the other hand, have preferred to stay in the labor force, which has led to increased incidence of unemployment. To summarize, unemployment has increased, while labor force participation, informal employment, and job finding rates have declined for natives. The disadvantaged groups - i.e., females, younger workers, and less-educated workers-have been affected the worst. We find a small, but unexpected, increase in formal employment among males, which we conjecture that is due to the increased presence of organizations to supply health, education, nutrition, security, childcare, and other services to the Syrian refugees located in the region. We conclude that the prevalence of informal employment in the Turkish labor markets has amplified the negative impact of Syrian refugee inflows on natives' labor market outcomes.

Our estimates are supplemented and supported by several robustness exercises. First, we replace our control area with a set of randomly selected regions from the rest of the Turkey. We find that the qualitative nature of the baseline results are unchanged. This exercise confirms that our estimates are not contaminated by effects specific to our control area. Second, we compare the outcomes in 2010-2011 with the outcomes in 2012 and 2013, separately. The main motivation behind this exercise is the fact that the total number of refugees is much higher in 2013 than 2012. Our findings show that, although the effects are statistically significant for both years, the estimates for 2013 are much larger than those for 2012. This result suggests that our estimates highly likely capture the refugee effects. Finally, we check whether the 
refugee inflows have generated a further wave of internal migration among natives from the treatment area to other regions in Turkey. We see that the net flows of domestic migration have remained unchanged in the post-immigration era both in the treatment and control areas.

Our paper contributes to the literature in three ways. First, this is the first paper attempting to estimate the causal effect of Syrian refugee flows on the labor market outcomes of natives in Turkey. We employ an original quasi-experimental design to estimate the changes in the outcomes of natives as a result of refugee inflows. Second, we highlight the importance of informal employment. We argue that the prevalence of informal employment in Turkey — which is around 35 percent as the end of 2014 - has amplified the impact of immigration on natives' outcomes. This suggests that the existence of a market for informal employment accelerates the diffusion of immigrant workforce into the labor markets of a hosting country. Finally, unlike the common perception, we find that the effect of immigration on natives' wages is ignorable. Our analysis covers a period of two years before and after the immigrant flows started; so, the estimated wage effects can be regarded as "short-term" estimates. Studies using the Israel data generally report that wage effects do not exist in the short-run, but they become large in long-run [see, e.g., Cohen-Goldner and Paserman (2011)]. The main difference between Israeli and Turkish cases is that the Russian immigrants to Israel were highly educated (perhaps more educated than the average native), while the Syrian immigrants to Turkey are, on average, low educated. This suggests that our wage estimates are somewhat less likely to change in the long run.

The rest of the paper is organized as follows. Section 2 provides detailed information on the process of refugee inflows from Northern Syria to Southeastern Turkey. Section 3 describes our data set and summarizes the main properties of our sample. Section 4 explains our econometric identification strategy. Section 5 discusses the empirical results. Section 6 performs various robustness checks. Section 7 concludes. 


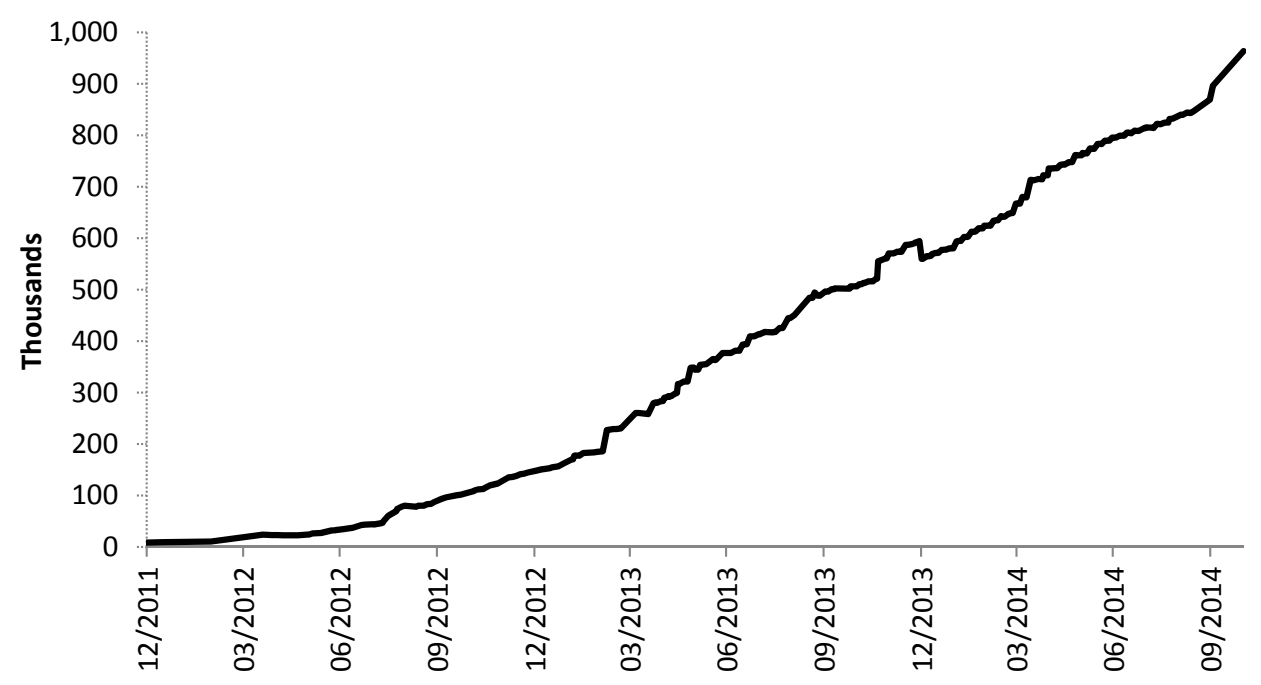

Figure 1: Number of registered Syrian refugees in Turkey (thousands). Source: UN Refugee Agency, http://data.unhcr.org/syrianrefugees/country.php?id=224.

\section{Contextual Details: Syrian Refugee Inflows}

Following the internal conflict in Syria, which started in March 2011, masses migrated from the Northern Syria to the Southeastern regions of Turkey. People caught under fire were forced to leave their homes in a short period of time. Most of the refugees came from provinces of intense conflict close to the Syrian-Turkish border. Cities where refugees came from and the fraction of the refugees in Turkey originated from the corresponding city can be listed as follows: Aleppo (36\%), Idlep (21\%), Raqqa (11\%), Lattika (9\%), Hassakeh (5.4\%), and Hama (7.5\%). These cities are very close to the Turkish border. The remaining $10 \%$ came from other cities relatively far from the border.

According to the UN figures, the number of registered refugees by the end of 2011 was only around 8,000 . Figure (1) shows that, by the end of 2013, the number of refugees has increased to 560,000 and the process is still ongoing. Initially, they were mostly based in the accommodation centers or camps constructed and operated by the Turkish government. But, in time, the refugee population living outside the camps has also increased. According to the survey results conducted by the Turkish Disaster and Emergency Management Presidency (AFAD), around three quarters of the Syrian refugees were living out of the camps as of June 2013.

\footnotetext{
${ }^{7}$ See AFAD (2013) for the details of the survey results.
} 


\begin{tabular}{|c|c|c|c|c|c|c|}
\hline & \multicolumn{3}{|c|}{ Number of Refugees } & \multicolumn{3}{|c|}{ Ratio of Ref. to Native Pop. (\%) } \\
\hline & In Camps ${ }^{(\mathbf{a})}$ & $\begin{array}{c}\text { Out of } \\
\text { Camps }^{(\mathbf{a})}\end{array}$ & Total $^{(\mathbf{a})}$ & $\begin{array}{c}\text { Tot. Ref. }{ }^{(a)} / \\
\text { Population }\end{array}$ & $\begin{array}{c}\text { Ref. Outside } \\
\text { Camps }^{(\mathbf{a})} / \\
\text { Population }\end{array}$ & $\begin{array}{c}\text { Tot. Ref. }{ }^{(\mathbf{b})} / \\
\text { Population }\end{array}$ \\
\hline \multicolumn{7}{|c|}{ Cities with camps } \\
\hline Sanliurfa & 73,295 & 45,000 & 118,295 & 6.6 & 2.5 & 9.4 \\
\hline Gaziantep & 32,696 & 90,000 & 122,696 & 6.7 & 4.9 & 11.9 \\
\hline Kilis & 27,247 & 10,000 & 37,247 & 29.0 & 7.8 & 38.1 \\
\hline Hatay & 15,404 & 60,000 & 75,404 & 5.0 & 4.0 & 12.6 \\
\hline Kahramanmaras & 14,970 & 10,000 & 24,970 & 2.3 & 0.9 & 4.1 \\
\hline Adiyaman & 9,893 & 300 & 10,193 & 1.7 & 0.1 & 0.4 \\
\hline Adana & 9,837 & 9,500 & 19,337 & 0.9 & 0.4 & 2.3 \\
\hline Osmaniye & 8,268 & 10,000 & 18,268 & 3.7 & 2.0 & 2.4 \\
\hline Malatya & 6,440 & 200 & 6,640 & 0.9 & 0.0 & 0.1 \\
\hline Mardin & 2,336 & 35,000 & 37,336 & 4.8 & 4.5 & 9.0 \\
\hline
\end{tabular}

Table 1: The Geographical Distribution of Syrian Refugees in Turkey (2013). The table reports the figures for Syrian refugees in cities with camps. The data come from two different sources: (a) Syrian population as of June 2013. Data source is AFAD report "Syrian Refugees in Turkey, 2013 Field Survey Results" dated 2013. (b) Refugee population as of January 2014, for which the data are released by the Ministry of Internal affairs in August 2014. There are also significant amount of refugees in some cities without official camps. The names of these cities and the corresponding refugee shares within the city population can be listed as follows: Sirnak (4\%), Batman (3.7\%), Mersin (2.6\%), Konya (2.2\%) and Istanbul (2.3\%). For the rest of the cities, the share of Syrian refugees is much below $1 \%$.

Majority of those living out of camps have reported that they left Syria for security reasons and they chose Turkey because of the ease of transportation. Main routes of entrance were Syrian-Turkish borders and most of them stayed in cities close to the borders.

Table (1) reports the number of refugees by hosting cities. There are 20 accommodation centers (camps) in 10 cities in Turkey. The accommodation centers are located in Adana, Adiyaman, Hatay, Gaziantep, Kahramanmaras, Kilis, Malatya, Mardin, Osmaniye, and Sanliurfa. Most of the Syrian refugees have been living in these or the neighboring cities. Although, there is a significant number of refugees in other regions of Turkey, such as Istanbul and Konya, their number is small relative to the population in these regions. Based on the refugee over population ratios, we observe that the refugees have been quite densely located in Kilis, Sanliurfa, Gaziantep, Hatay, Osmaniye, and Mardin [see Table (1)]. Strikingly, the refugeepopulation ratios amount up to 30 percent in Kilis. In these cities, refugees have significantly increased the local population with a high potential to affect the labor market outcomes of 


\begin{tabular}{|c|c|c|c|c|c|c|c|c|}
\hline & \multicolumn{2}{|c|}{ Refugees } & \multicolumn{6}{|c|}{ Natives (in 2013) } \\
\hline & \multirow[b]{4}{*}{ In Camps } & \multirow{4}{*}{$\begin{array}{l}\text { Out of } \\
\text { Camps }\end{array}$} & \multirow{4}{*}{$\begin{array}{l}\text { Adana } \\
\text { Mersin }\end{array}$} & \multirow{4}{*}{$\begin{array}{c}\text { Hatay } \\
\text { K.Maras } \\
\text { Osmaniye }\end{array}$} & \multirow{4}{*}{$\begin{array}{c}\text { G.Antep } \\
\text { Adiyaman } \\
\text { Kilis }\end{array}$} & \multirow{4}{*}{$\begin{array}{c}\text { Diyarbakir } \\
\text { Sanliurfa }\end{array}$} & \multirow{4}{*}{$\begin{array}{l}\text { Mardin } \\
\text { Siirt } \\
\text { Batman } \\
\text { Sirnak }\end{array}$} & \multirow[b]{4}{*}{ Overall } \\
\hline & & & & & & & & \\
\hline & & & & & & & & \\
\hline & & & & & & & & \\
\hline \multicolumn{9}{|l|}{ Gender } \\
\hline Male & 51.4 & 51.4 & 49.7 & 49.4 & 48.7 & 49.1 & 49.0 & 49.2 \\
\hline Female & 48.6 & 48.6 & 50.3 & 50.6 & 51.3 & 50.9 & 51.0 & 50.8 \\
\hline \multicolumn{9}{|l|}{ Age Groups } \\
\hline $1-12$ & 36.7 & 34.0 & 24.9 & 28.5 & 30.9 & 32.2 & 27.0 & 24.9 \\
\hline $13-18$ & 16.3 & 14.9 & 12.2 & 13.1 & 14.8 & 15.5 & 13.1 & 12.2 \\
\hline $19-54$ & 42.4 & 45.0 & 48.3 & 47.3 & 45.0 & 44.1 & 48.0 & 48.3 \\
\hline $55-64$ & 2.8 & 3.7 & 8.0 & 5.4 & 5.0 & 4.5 & 6.5 & 8.0 \\
\hline $65+$ & 1.7 & 2.4 & 6.6 & 5.7 & 4.3 & 3.6 & 5.4 & 6.6 \\
\hline \multicolumn{9}{|c|}{ Educational Attainment } \\
\hline Illiterate & 12.3 & 18.8 & 10.6 & 13.9 & 14.5 & 23.0 & 19.3 & 15.9 \\
\hline Literate (no degree) & 5.5 & 9.5 & 13.7 & 15.1 & 18.7 & 25.2 & 23.1 & 18.7 \\
\hline Primary School & 36.6 & 33.0 & 33.7 & 35.9 & 31.6 & 24.1 & 23.8 & 30.3 \\
\hline Middle School & 24.7 & 19.4 & 18.0 & 18.3 & 18.9 & 17.0 & 20.4 & 18.3 \\
\hline High School & 13.2 & 9.6 & 15.5 & 10.9 & 10.0 & 7.2 & 9.1 & 10.8 \\
\hline Higher Education & 7.8 & 9.7 & 8.6 & 5.9 & 6.3 & 3.6 & 4.2 & 5.9 \\
\hline
\end{tabular}

Table 2: Demographic Characteristics of Refugees vs Natives. The demographic characteristics of the Syrian refugees come from a survey conducted by AFAD in June 2013 (Syrian Refugees in Turkey, 2013 Field Survey). For the demographic characteristics of natives, we use the Turkish Household Labor Force Survey 2013 micro data set.

the natives. Syrian refugees are not officially allowed to work in Turkey as registered workers. The Turkish labor market, especially the labor market in the Southeastern Turkey, offers extensive informal employment opportunities. Syrian refugees, albeit not being permitted to work formally, are willing to be employed informally. In fact, according to survey results, about three quarters of the refugees are looking for a job.

Next, we look at the summary statistics for the demographic characteristics of the Syrian refugees in terms of gender, age, and educational attainment. These figures give us a preliminary idea about the potential impact of the refugee flows on the labor market outcome of the native population. The Syrian refugees and Turkish natives have similar educational characteristics, implying that the refugee labor supply is likely to be a substitute for native workers living in the Southeastern Turkey [Table (2)]. 
As reported in Table (2), the gender composition of the refugees is more or less balanced. The majority of the refugees are of the core working age group (19-54) and, on average, the refugees have low education. For around $80 \%$ of the refugee population, the level of education is less than high school. The share of refugees with less than a middle school degree is almost $55 \%$. This educational profile bares notable resemblance to that of the natives residing in the hosting regions. Looking at the last column in Table (2), the overall share of natives in the region with educational attainment below high school and middle school are $83 \%$ and $65 \%$, respectively.

Overall, these institutional details suggest that: (1) the Syrian refugees are forced to enter Turkey and the pace of inflow is high; (2) the refugees are clustered into certain regions due to reasons that are not fully determined by their own locational preferences. The camps and accompanying public services as well as proximity to home have been the main determinants; and (3) the demographic and educational composition of the refugees is comparable to that of the natives living in the hosting regions suggesting that the potential for substitutability in the workforce is high. This setting suggests that both the decision to migrate and the location choice of the refugees are not entirely controlled by them; thus, there is a good opportunity to setup a quasi-experimental design to estimate the causal impact of Syrian refugees on natives' labor market outcomes.

\section{$3 \quad$ Data and Summary Statistics}

In all of our estimations, we employ micro-level labor market data for natives. We use the Turkish Household Labor Force Survey micro-level data sets compiled and published by the Turkish Statistical Institute (TURKSTAT). The TURKSTAT Labor Force Surveys (LFS) are designed as repeated cross-sectional surveys with no panel dimension. They are nationallyrepresentative and publicly-available. The LFS micro-level data sets are released in annual frequency and have very large sample sizes even at regional level. ${ }^{8}$ We observe a rich set of labor market variables along with individual-level characteristics and the region of residence,

\footnotetext{
${ }^{8}$ The national labor force statistics for Turkey are produced from the monthly LFS surveys. However, micro-level details of these monthly surveys are not publicly available.
} 
which is particularly useful for our purposes. We use four consecutive waves of the LFS, from 2010 to 2013.

The difference-in-differences exercise we perform compares the outcomes of the natives in the regions that receive refugees to those that don't receive, before and after immigration. Since the cutoff date is January 1st, 2012, the pre-immigration period is 2010-2011, while the post-immigration period is 2012-2013. The criteria for being an immigrant-hosting city are: ( $i$ ) being close to the Syrian border and ( $i i)$ having a refugee/population ratio of 2 percent or above. Our sample includes 9 regions out of 26 regions in Turkey determined according to the NUTS2 classification. ${ }^{9}$ The treatment area includes 5 regions from the Southeastern Anatolia, whereas the control area includes 4 regions from Eastern Anatolia. See Section 4 for more details on our choice of treatment versus control areas along with the details of our identification strategy.

The LFS provides detailed information about the respondents' social and demographic characteristics such as age, education, and marital status. The LFS also contains extensive information about the individuals' labor market outcomes, including current and past labor market status, occupation, industry, formality status, firm size, previous employment sector, job-search preferences, earnings, and duration of unemployment. For the purpose of focusing on the outcomes of the natives, we exclude from our sample the individuals who were born outside of Turkey and entered the country after 2010. Children that are younger than 15 years old and individuals who are 65 and older are also dropped from our sample. As a result, our sample has 354,023 individual observations from the selected 9 regions for the period of analysis, 2010 - 2013. The demographic characteristics of the individuals in our sample are provided in Table (3). Appendix A provides a very detailed description of the variables used in the empirical analysis.

We observe that social and demographic characteristics of individuals from treatment and control areas are quite similar. Moreover, their social and demographic characteristics did not change significantly between 2010 and 2013. The fraction of young individuals, who are at

\footnotetext{
${ }^{9}$ See Appendix B for the details of NUTS2-level regional classification in Turkey.
} 
the early years of their working lives, is high in our sample, but the ratio of high school and university graduates to regional population is quite low in the treatment and control areas [Table (3)].

There are some differences between treatment and control areas with respect to the levels of the main labor market outcomes. The employment and labor force participation rates are lower in the treatment area compared to the control area, whereas the unemployment rate is higher in the treatment area [Table (4)]. A significant majority of the respondents are in full-time employment in both treatment and control areas. Approximately half of all working individuals are employed in the informal sector in the treatment area and this ratio is even higher in the control area. There are also some differences in terms of the urbanization rates [Table (3)]. The treatment area is somewhat more urbanized than the control area. It is possible to attribute the differences in labor market outcomes to the differences in urbanization rates. To capture this possibility, we control for urban/rural residency status in our regressions.

\section{Empirical Analysis}

In this section, we describe the details of the identification strategy that we use in this paper and we present our econometric specification. In our empirical analysis, we employ a difference-in-differences (DID) estimation, which is widely used in the recent program evaluation literature. ${ }^{10}$ The advantage of this method is that, as long as there exists a natural experiment that leads to a differentiation between two groups along two consecutive time periods, it is possible to obtain causal estimates using data sets that can be labeled as "pooled cross sections over time."

Identification strategy. The classical approach in assessing the impact of immigration on the labor market outcomes of natives is to regress the labor market outcome of interest on the share of immigrants in the relevant region along with other controls. The coefficient of the immigrant share is then interpreted as the impact of immigration on natives' labor market outcomes. The existence of regional variation in immigrant shares is the source of identifica-

\footnotetext{
${ }^{10}$ See Angrist and Pischke (2008) and Wooldridge (2010) for detailed background information about DID estimators.
} 
tion. However, it is well-known that this approach suffers from an endogeneity problem due to self-selection of immigrants into the regions with high labor market returns. To overcome this endogeneity problem, either a valid instrumental variable or a convincing quasi-experimental design is needed.

The civil war in Syria has led to a massive wave of forced immigration from the Northern Syria to the Southeastern regions of Turkey. The Turkish government has established several refugee camps near the Southeastern border to accommodate the refugees until the conflict in Syria is resolved. As we describe in Section 2, the border cities in the Southeastern region of Turkey are hosting large numbers of Syrian refugees. The main sources of this clustering are the proximity to Syria and the existence of government-operated camps as well as other supplementary regulations put into force in these cities. Many of the neighboring regions, however, have received only few refugees amounting to a tiny fraction of the population in these regions. This situation resembles a natural experiment that leads to massive immigrant inflows into certain cities - in the range of 2 to 30 percent of the total population in these cities - while other surrounding regions have not received important inflows of refugees. The surrounding regions are quite similar to the hosting regions in terms of cultural background, social norms and attitudes, level of economic development, and labor market characteristics. As a result, we label the hosting regions as the "treatment area," while the surrounding regions are called the "control area."

Figure (2) presents a visual characterization of our treatment and control areas. The treatment area consists of 5 NUTS2-level regions consisting of cities for which the refugee/population ratio is above 2 percent. The treatment area is marked with darker gray color on the map. The cities in the treatment area include Kilis, Osmaniye, Gaziantep, Kahramanmaras, Sanliurfa, Batman, Diyarbakir, Adiyaman, Sirnak, Siirt, Adana, Mardin, Hatay, and Mersin. ${ }^{11}$ The control area consists of 4 NUTS2-level regions with refugee/population ratios very close to 0. The cities in the control area are Erzurum, Erzincan, Elazig, Malatya, Mus, Van, Kars,

\footnotetext{
${ }^{11}$ Notice that for Adiyaman, Diyarbakir, and Siirt, the refugee/population ratios are less than 2 percent. The data set allows us to identify only the regions not the cities. For example, we know that the individual is residing in the Sanliurfa-Diyarbakir region, not specifically in Diyarbakir or Sanliurfa. Therefore, we include these cities into our treatment area because the NUTS2-level classification groups these cities with the cities with high refugee densities.
} 


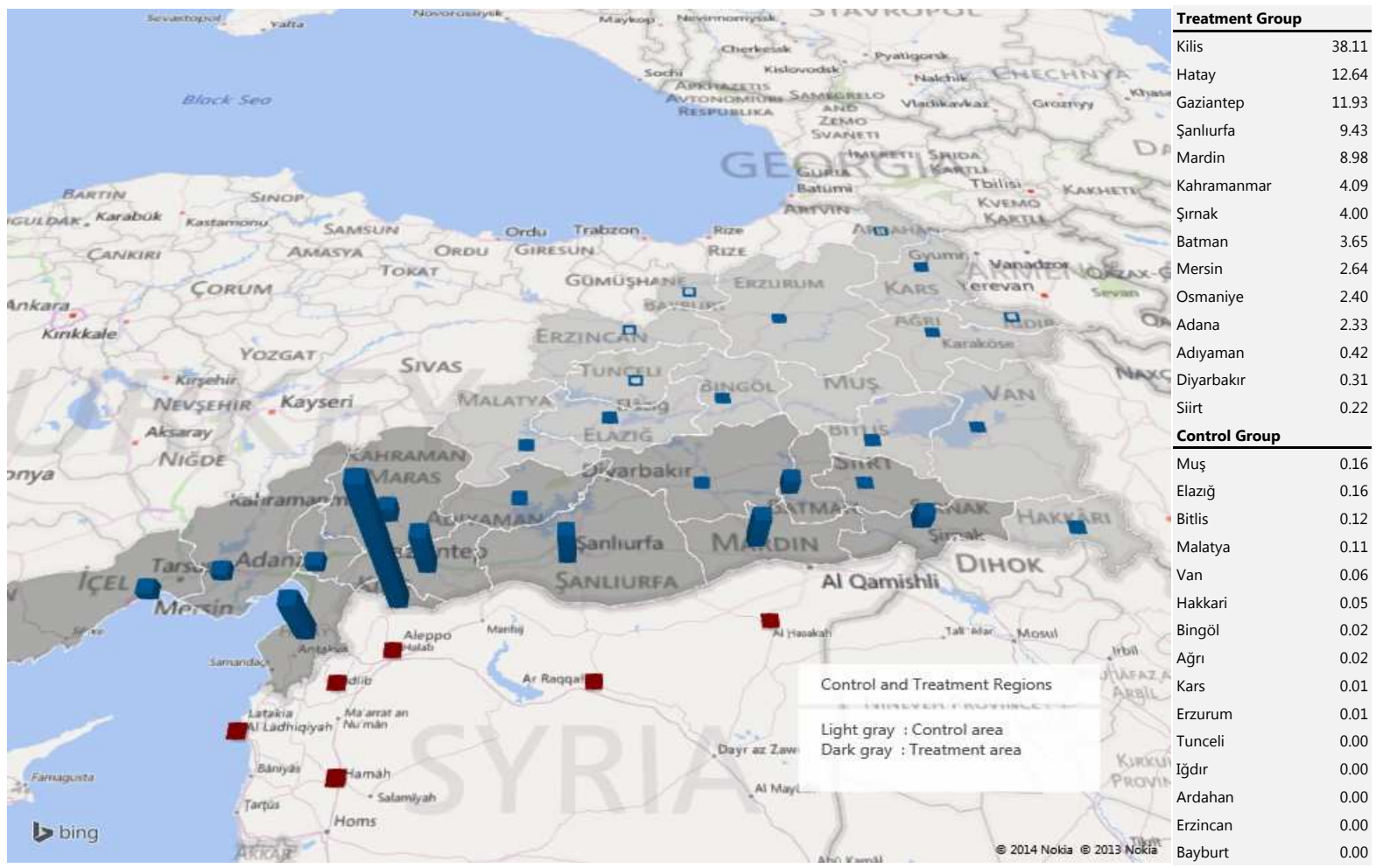

Figure 2: Visual display of treatment and control areas. The dark gray area is the treatment area, while the light gray area describes the control area. The blue bars measure the refugee/population ratios in the corresponding cities. The refugee/population ratios are also provided on the right of the figure. For example, the number of refugees is 38.11 percent of the native population in Kilis. The red squares indicate the major source cities in Syria.

Ardahan, Agri, Igdir, Hakkari, Bingol, Tunceli, Bayburt, and Bitlis. The control area is indicated with light gray on the map. ${ }^{12}$ The treatment and control areas are not only very close to each other in terms of cultural background, social norms and attitudes, and level of economic development, but they are also quite similar in terms of the prior trends of the main labor market outcomes. Figure (3) plots the pre-immigration trends for employment, unemployment, and labor force participation variables in the treatment versus control areas and documents these similarities in prior trends. Note that, in Section 6, we try alternative control areas constructed from other regions in Turkey and show that our estimates are not specific to our choice of the control area.

Figure (1) suggests that the refugee inflows have basically started after January 2012. Taking this date as the cutoff point, we construct a symmetric window that sets $2010-2011$ as the pre-immigration period and 2012-2013 as the post-immigration period. Existence of a treat-

\footnotetext{
${ }^{12}$ See Appendix B for a comprehensive description of the NUTS2-level regional division in Turkey.
} 
ment area, a control area, a pre-immigration period, and a post-immigration period allows us to perform a DID analysis to estimate the impact of immigration on the labor market outcomes of the natives. In a nutshell, this identification strategy aims at estimating the impact of immigration on the labor market outcomes of natives by comparing the pre- and post-immigration outcomes in the treatment area to those in the control area. Next we present the details of the econometric specification.

Econometric specification. To set a formal language on econometric specification, we construct a dummy variable $R$ taking 1 in the treatment area, 0 in the control area and another dummy variable $T$ taking 1 in the post-immigration period, 0 in the pre-immigration period. Our DID equation is formulated as follows:

$$
y_{i, j, t}=\alpha+\gamma \cdot R_{i}+\phi \cdot T_{i}+\beta \cdot\left(R_{i} \times T_{i}\right)+\boldsymbol{\theta}^{\prime} \cdot \boldsymbol{X}_{i, j, t}+\kappa \cdot Z_{j, t}+\epsilon_{i, j, t},
$$

where $i, j$, and $t$ index individuals, regions, and years, respectively, $y$ is the labor market outcome of interest, $\boldsymbol{X}$ is a vector of individual-level characteristics, $Z_{j, t}$ is a region- and timespecific proxy for economic activity, and $\epsilon$ is an error term. The main parameter of interest is $\beta$, which yields the change in the labor market outcome of natives in the treatment area as a result of the refugee flows. The proxy for region level activity is included to control for the fact that the impact of Syrian civil conflict on labor market outcomes might also operate through its impact on economic activity. The individual-specific variables are included to capture the differences in labor market outcomes due to differences in their observed characteristics. A full list of control variables along with their detailed descriptions can be found in Appendix A.

It is also possible to express the DID regression by dropping $R$ and $T$, and including a full set of region and year fixed effects denoted by $f_{j}$ and $f_{t}$, respectively. So, the DID equation can also be written as follows:

$$
y_{i, j, t}=\alpha+\beta \cdot\left(R_{i} \times T_{i}\right)+\boldsymbol{\theta}^{\prime} \cdot \boldsymbol{X}_{i, j, t}+\kappa \cdot Z_{j, t}+f_{j}+f_{t}+\epsilon_{i, j, t} .
$$


This reformulation is fully consistent with the spirit of the standard DID analysis and can be used in the regressions spanning several years and regions [see, e.g., Carpenter (2004) and Wooldridge (2010)]. Since we are not directly interested in the coefficients $\gamma$ and $\phi$, we use the second specification in our regressions.

\section{$5 \quad$ Results and Discussion}

In this section, we present the estimated effect of the refugee inflow on the labor market outcomes of natives in the Southeastern regions of Turkey. First, we present the estimated effect of the refugee inflows on the labor market status of native individuals. We construct four mutually exclusive labor market outcomes for the native population of age 15-64: $(i)$ not in labor force, $(i i)$ formal employment, (iii) informal employment, and (iv) unemployment. Accordingly, we generate four separate binary indicators for these outcomes within the whole sample of natives of age 15-64. ${ }^{13}$ For example, the binary indicator for being formally employed takes the value 1 if an individual has a formal job, and 0 otherwise. ${ }^{14}$ Using a difference-indifferences strategy, we investigate the displacement effect of the refugee inflow and examine if displaced natives stay in the labor force or exit from the market. Refugee inflows may also affect the earnings of the native individuals. Accordingly, we analyze the refugee effect on the monthly wages of employed natives working for a salary. In all tables, the first two columns present the estimated effects for the total population of interest. The next two columns present the estimates for men and women separately, and the last two columns present the estimates for individuals with no high school degree and individuals with high school degree or above, separately.

We would like to note that the economic activity in the treatment area may partially depend on trade relationships with Syria both in terms of exports and imports. So, changes in labor market conditions after the civil conflict has started in Syria may partially depend on changes in trade volumes as well as inflow of Syrian refugees. To control for this possibility, we include

\footnotetext{
${ }^{13}$ See Appendix A for further details on the construction of these variables.

${ }^{14}$ Note that the sample is not the labor force, but the total native population of age $15-64$. In each regression we examine the likelihood of being in a labor market status within the whole population.
} 
trade volumes $\left(Z_{j, t}\right)$, defined as exports plus imports, by regions and years into our regressions. Since we employ a DID strategy, the trade volumes are included both for the treatment and control areas, which means that the impact of trade volume on labor market outcomes in the treatment area relative to the impact in the control area is accounted for. The first column in each table excludes the proxy for regional economic activity, while the second column includes it.

Table (5) reports the effect of the refugee inflow on the likelihood of informal employment for natives. The dependent variable is a binary indicator that takes the value 1 if an individual has an informal job and 0 otherwise. ${ }^{15}$ The first column shows that the refugee inflow to the treatment areas in Turkey reduces the likelihood of having an informal job by 2.2 percentage points for natives in those regions compared to the natives in the control areas. In the second column, we control for the annual trade volumes of the corresponding regions. The results are nearly the same implying that the refugee inflow drives the estimated effects rather than the changing economic activity of the regions. The third and the fourth columns illustrate that the effect is statistically significant among both men and women with a larger magnitude among women. The last two columns show that the effect is concentrated among less-educated individuals - i.e., the ones with no high school degree.

The interpretation of the change in informal employment requires careful consideration. Having an informal job is quite common in Turkey and can be considered as the second-best outcome for unemployed individuals. Therefore a decline in the likelihood of having an informal job is considered as a negative consequence, unless they switch to formal employment. As will be explained later, in the current context, most of those who lose their informal jobs either exit the labor force or stay unemployed. We examine the transition in further detail later in the text.

Those who lost their informal jobs switch to one of the remaining three labor market status. They either exit the labor force, stay unemployed, or find a formal job. Table (6) reports the

\footnotetext{
${ }^{15}$ Informal job holders are the ones who are employed, but do not have a social security coverage. See Appendix A for a detailed description of the dependent and independent variables.
} 
estimated effect of the refugee inflows on the labor force participation of native individuals in the Southeastern regions of Turkey. The sample is the same as the one in Table (5). The dependent variable is a binary indicator that takes the value 1 if an individual is in the labor force and 0 otherwise. The second column shows that the refugee inflows reduce the labor force participation of native individuals in the treatment area by 1.1 percentage points compared to the natives in the control area. The third and the fourth columns illustrate that the effect is mostly driven by women. The estimated effect is positive, but statistically insignificant among men, while it is negative and statistically significant among women. The last two columns show that the effect is concentrated among individuals with low levels of education.

Table (7) shows the estimated effect of the refugee inflows on the unemployment of native individuals in the Southeastern regions of Turkey. Again, the sample is the same as Table (5) and Table (6), and includes all individuals of age 15-64 regardless of their labor force participation status. The first two columns show that the rate of unemployed individuals in total population in the treatment area has increased by 0.7 percentage points after the refugee inflows. The next two columns illustrate that the effect is statistically and economically significant among men and insignificant among women. The last two columns show that the effect is driven by individuals with no high school degree. Finally, Table (8) reports the estimated effect of the refugee inflows on the likelihood of having a formal job among native individuals in the Southeastern regions of Turkey. The first two columns show that the likelihood of having a formal job among native individuals in the treatment areas has increased by 0.4 percentage points compared to the natives in the control areas after the refugee inflow. The next four columns show that the effect is concentrated among men and individuals with low education levels.

Overall, we find that the likelihood of having an informal job has declined by 2.2 percentage points for native individuals in the treatment area regions as a consequence of the refugee inflow. Of this decline in the informal employment, 1.1 percentage points went out of the labor force, 0.7 percentage points remained unemployed, and 0.4 percentage points switched to a formal job. For men, the decline in the informal employment likelihood is 1.9 percentage 
points. Men who lost their informal jobs do not exit from the labor force. For women, the decline in the likelihood of having an informal job is much higher, 2.6 percentage points. Unlike men, we do not find any increase in the unemployment or formal employment likelihood of women. We find that all women who lost their informal jobs went out of the labor force. This can be explained by the low labor-market attachment levels among the informally employed women.

We should also note that finding a negative effect on informal employment is in line with the legal regulations regarding the Syrian refugees. Refugees hosted and accommodated by the Turkish government do not have working permits. Therefore, it is very unlikely for refugees to substitute for the formally employed individuals. Moreover, due to cultural and language barriers, refugees cannot utilize their labor market experience and skills in the Turkish labor market. ${ }^{16}$ Thus, it is in line with our expectations to see the negative effect concentrated among native individuals with no high school degree.

Next, we investigate the effect of the refugee inflows on the job separation and job finding probabilities of the native individuals. Table (9) shows the effect of the refugee inflows on the job separation probability of native individuals in the treatment areas. The sample includes all individuals aged 15-64, who were employed exactly one year ago. The binary indicator takes the value one if an individual was employed last year but not employed now. We do not observe any effect of the refugee inflow on the job separation probability of native individuals. Table (10) repeats the same exercise for the job finding probability. The sample in Table (10) includes all individuals aged 15-64, who were not working and were actively seeking for a job exactly one year ago. The binary indicator takes the value one if an individual who was unemployed last year currently has a job. The estimates are negative and statistically significant. Both men and women in the treatment areas have a harder time in finding a job compared to those in the control areas after the refugee inflows. The effect is concentrated among individuals with no high school degree. These two tables suggest that the effect of the

\footnotetext{
${ }^{16}$ This is also related to the human capital non-transferability argument made by Cohen-Goldner and Paserman (2011). They emphasize that the new immigrants may not fully utilize their human capital in the host country, since the labor market in the host country may not immediately price the skills transferred from the source country to the host country. No work permit, as in the case of Syrian refugees in Turkey, can amplify this non-transferability effect.
} 
refugee inflow happens through reducing the job finding probability, rather than raising the separation probability.

Table (11) summarizes the results of the DID regressions for all of the labor market outcomes described above by age groups. We focus on six equally-spaced age groups ranging between 15-24 and 55-64. We find that the effects summarized above have mostly operated through young individuals - i.e., those below 35. In particular, the patterns of losing informal jobs and either remaining unemployed (for young males) or leaving the labor force (for young females) are most prevalent for individuals younger than 35 .

Finally, we examine the effect of the refugee inflows on natives' wages. Table (12) and Table (13) examine the effect of the refugee inflows on the real monthly earnings of formal and informal employees, respectively. The samples in Table (12) and Table (13) include employed native individuals aged 15-64, who work for salary. The dependent variable is defined as the log of the real monthly earnings. Overall, we do not find statistically significant effect of the refugee inflow on the real wages of the native individuals. We have also performed regressions for new hires only, rather than the whole sample of wages. ${ }^{17}$ Our result is unchanged: the refugee inflows do not have any statistically significant effect on natives' wages even after conditioning the regressions on new hires only.

It will perhaps be useful to review these results in the light of the existing literature relying on quasi-experimental techniques to estimate the impact of immigration on the labor market outcomes of natives. Card (1990) documents that the Mariel Boatlift of Cubans to Miami in 1980 had virtually zero effect on the labor market outcomes of the existing Miami residents. Hunt (1992) reports that the 1962 Algerian repatriates only had a negligible effect on the labor market outcomes in France. Friedberg (2001) finds that the rapid and unexpected inflow of Russian immigrants to Israel had almost no adverse effects on the labor market outcomes of natives. Glitz (2012) analyzes the impact of the labor supply shock generated by the collapse of Berlin wall on the labor market outcomes in Germany. He documents that the employment outcomes have been negatively affected, while the effect on wage outcomes have been nil.

\footnotetext{
${ }^{17}$ Pissarides (2009) finds that wages of new hires are likely more responsive to the changes in labor market conditions.
} 
Our paper is similar to all these papers in the sense that the wage outcomes have not been affected, while we observe some negative effects on employment outcomes of the natives. The distinctive feature of our paper is that we identify informality as the main channel through which the impact of immigrants on the labor market outcomes of natives operates.

\section{Robustness Checks}

In this section, we perform two distinct robustness exercises to check the relevance of the baseline results. First, we replace our control areas (i.e., the Eastern Anatolia) with 12 different randomly selected alternative control areas chosen among the other regions of Turkey excluding the treatment areas and the original control areas. The same DID regressions are performed separately for these 12 alternative control areas, holding the treatment area fixed. If our baseline results are robust, than we should not observe any significant change in the qualitative nature of our results from these regressions. Second, we hold the pre-treatment period as 20102011, but change the post-treatment period as only 2012 and only 2013. The motivation for this exercise is provided by Figure (1), which suggests that the refugee inflows were much more intensive in 2013 than 2012. Thus, if our estimates indeed reflect "refugee effects," we should see larger coefficients when we set only 2013 as the post-treatment period relative to the case in which we set only 2012 as the post-treatment period.

We start with the first exercise. The control area that we use in our baseline analysis is pretty much similar to the treatment area in terms of socio-demographic characteristics, economic development levels, cultural factors, and labor market conditions. Despite this similarity, we carry out robustness checks to make sure that results are not driven solely by the choice of the control area. In doing so, we compare the treatment area with 12 different randomly selected alternative control areas. These areas are selected from a pool of 15 regions in groups of $4 .^{18}$

Table (14) reports the results of these exercises for the four main labor market outcomes:

\footnotetext{
${ }^{18} \mathrm{We}$ also exclude the Istanbul and Konya regions. These regions are not considered eligible, because they have received non-negligible numbers of refugees amounting up to 2 percent of their native population. These regions are also excluded from the treatment area for two reasons: first these cities are large and subject to many outside factors apart from the Syrian refugee flows and second they have different socio-demographic features and economic development levels compared to the other regions within the treatment area.
} 
informal employment, labor force participation, unemployment, and formal employment. The descriptions of these variables are identical to the original regressions. The regressions are performed for the total population of interest and the specification includes the annual trade volume as well as all the remaining control variables. Thus, the results reported in Table (14) are fully comparable to those reported in the second columns of the main tables in Section 5 .

We find that the results from the regressions with alternative control areas are reasonably similar to the results obtained in our baseline analysis, which justifies the validity of the results presented and discussed in Section 5. Similar to our main results, the likelihood of having an informal job is significantly lower in the treatment area irrespective of the control area. We also find that the labor force participation rates decline significantly in the treatment area relative to the alternative control areas. Strikingly, for most of the regressions, the size of the impact is even more pronounced compared to the baseline regressions. As reported in Table (6), the refugee inflows to the treatment area reduce the labor force participation rates by 1.1 percentage points for natives compared to the natives in the control area. When the original control area is replaced with the alternative control areas, this impact takes a much larger value - mostly within the range of -1.6 to -4.0 percentage points. We find that, for some groups (around one thirds of them), there are slight differences between the baseline and alternative regressions in terms of unemployment and formal employment. One potential reason for this small discrepancy might be related to diversification in regional labor force participation trends. Overall, our robustness exercises justify the validity of the baseline results presented in Section 5 .

Table (15) reports the results of our second robustness exercise. We find that for all four outcomes of interest, the refugee effect is much larger in 2013 than 2012. For informal employment, the effects for 2012 and 2013 are -1.3 and -3.2 percentage points, respectively. For labor force participation, the refugee effects are estimated to be -0.85 and -1.2 percentage points for 2012 and 2013, respectively. For unemployment, the corresponding effects for 2012 and 2013 are 0.3 and 1.2 percentage points, respectively. Finally, for formal employment, there is not any statistically significant effect in 2012, while, in 2013, the refugee effect is 
approximately 0.8 percentage points. This is consistent with the differences in the volume of refugee inflows across 2012 and 2013. As Figure (1) suggests, the inflows were almost more than doubled in 2013 relative to 2012. Our estimates documented in Table (15) are in line with these figures.

As a separate exercise, we also check whether the refugee inflows have generated a further wave of internal migration from the treatment area to the other regions of Turkey. This is the criticism posed by Borjas, Freeman, and Katz (1996): if the refugee inflows push the natives in the hosting region toward other regions, then the estimates would be biased by the fact that the natives would selectively stay in the region. To check this possibility, we use the internal migration statistics compiled and published in annual frequency by the Turkish Statistical Institute. Micro-level details are not available. For each city, the internal migration per year is described by two numbers: inflow and outflow. We construct yearly gross and net numbers for the treatment and control areas that we use in our baseline analysis. Looking at the figures from 2007 to 2013, we observe that there is no visible change in the trends of internal migration both for the treatment and control areas. This provides suggestive evidence that our estimates are not contaminated by internal migration waves triggered by refugee inflows.

\section{Concluding Remarks}

The recent forced inflow of Syrian refugees to Turkey due to severe civil conflict in Syria provides a natural experiment that allows us to study the impact of immigration on labor market outcomes of natives in Turkey. Using a difference-in-differences strategy motivated by the regional variation in refugee settlement patterns in Turkey, we find that refugee inflows have had considerable effects on the employment outcomes of the Turkish natives, while there is no statistically significant effect on wages. Specifically, we find that refugee inflows have reduced the informal employment to population ratio by approximately 2.2 percentage points - 1.9 and 2.6 percentage points for males and females, respectively. The informal employment outcomes have been affected the most, because the Syrian refugees are not allowed to work officially and they are mostly uneducated; thus, they can only diffuse into the Turkish labor market through 
informal employment. The behavior of the displaced natives differs across males and females. The displaced males have mostly remained unemployed, while the displaced females have left the labor force. Various robustness exercises confirm the validity of the baseline estimates. We conclude that the forced inflow of Syrian refugees from the Southeastern border of Turkey, have negatively affected the employment outcomes of natives in the treatment area relative to the control area, but the wage outcomes have mostly remained unaffected.

Our paper contributes to the literature that estimates the impact of immigration on the labor market outcomes of the natives. In particular, our work is most closely related to the strand of this literature focusing on exogenous refugee inflows rather than voluntary immigration. The problem of Syrian refugees is of primary importance for many countries in the region. By now, it is clear that the refugee problem will not only have short-term impacts, but it will also impose several long-term consequences on the hosting countries. These consequences span a large horizon of topics including economic, social, and political outcomes. It will not be surprising to see that there will be a surge of new research on the impact of Syrian refugees on most of these outcomes as new data sets with greater micro-level details become available. Our paper is only a first effort in uncovering the economic impacts of the Syrian refugees on the hosting regions. 


\section{A Description of Variables}

In this appendix, we provide detailed descriptions of the concepts we have defined throughout the paper as well as the variables we have used in the regressions.

\section{General Definitions:}

- Native population: Among those who were born in foreign countries (i.e., countries other than Turkey), the ones who started to reside in Turkey after 2010 are excluded for the purpose of focusing on the impact of Syrian refugees. After this trimming, all remaining workers in the age interval 15-64 constitute the native worker population relevant for our analysis.

- Treatment period $(T=1)$ : The treatment period is defined to be $2012-2013$. This is the period right after the entrance of Syrian refugees into the country. In the text, we also use the term post-immigration period.

- Control period $(T=0)$ : The control period is defined as 2010-2011. This is the period right before the entrance of Syrian refugees. In the text, we also use the term pre-immigration period.

- Treatment area $(R=1)$ : The treatment area consists of 5 regions with numbers 12 , 13, 24, 25, and 26 - categorized based on the NUTS2 system (the Appendix B, Table A, provides the details of the NUTS2 regional categorization for Turkey). This is the area in which the Syrian refugees have been densely accommodated.

- Control area $(R=0)$ : The control area consists of 4 regions with numbers 20, 21, 22, and 23- see the Appendix B below for the descriptions of these numbers. The control area is very similar to the treatment area in terms of the socio-demographic characteristics and the level of economic development. The pre-immigration trends of the main labor market outcomes are also similar across the treatment and control areas [see Figure (3)].

- Refugee effect $(R \times T)$ : This is the variable that we use to identify the causal effect of immigration on natives' labor market outcomes. The cross product reflects the usual 
spirit of the difference-in-differences approach.

- Informal employment: The informal employment is defined by a dummy variable taking 1 if the worker is NOT registered with the social security institution in his current job and 0 if he is registered. The relevant population is the "native worker population" as described above.

- Formal employment: The formal employment is described by a dummy variable taking 1 if the worker is registered with the social security authority in his current job and 0 if he is NOT registered. The relevant population is, again, the "native worker population" as described above.

- Unemployment: Unemployment is described by a dummy variable taking 1 if the worker is not working but actively seeking for a job and 0 otherwise. The relevant population is the "native worker population" as described above. Notice that, on aggregate, this variable is describing the unemployment-to-population ratio, rather than the traditional unemployment rate.

- Labor force participation: The labor force participation variable is described by a dummy variable taking 1 if the worker is either unemployed, formally employed, or informally employed, and 0 if the worker is not in labor force. The relevant population is the "native worker population" as described above.

- Job separation indicator: The job separation variable is described by a dummy variable taking 1 if the worker was employed one year ago and is currently non-employed, and 0 otherwise. The only information in the survey regarding employment status history comes from the question asking the employment status of the worker exactly one year before the interview.

- Job finding indicator: The job finding variable is described by a dummy variable taking 1 if the worker was not working but actively seeking for a job one year ago and is currently employed, and 0 otherwise. 
- Marital status: The variable used to describe the marital status of the individuals is a dummy variable taking 1 if the worker is married and 0 otherwise.

- Low education: The education variable is described in 6 categories in the Turkish Household Labor Force Survey: 1 - no degree, 2 - primary school, 3 - middle school, 4 - high school, 5 - vocational high school, and 6 - college or above. In the paper, we define the workers with low education by a dummy variable taking 1 if the worker is a high school dropout, i.e., below (excluding) category 4.

- High education: Individuals with high education levels are described by a dummy variable taking 1 if the individual has a high school degree or above, i.e., above (including) category 4.

- Urban/rural status: Whether the worker resides in an urban versus rural area is described by a dummy variable taking 1 if the worker lives in an urban area and 0 otherwise. In the survey, an urban area defined as a residential area with population size above 20,000 .

- Trade volume: The trade volume is defined as the sum of exports and imports denominated in USD. The data source is the Foreign Trade Statistics released by the Turkish Statistical Institute.

Other general variables that do not need any description include gender, age, region (NUTS2), and year dummies.

\section{Variables in the earnings regressions:}

- Real earnings: The earnings variable describes the worker's monthly earnings including the monthly salary plus bonuses, performance pays, overtime pays earned in the corresponding month. The nominal earnings is deflated (taking 2010 as the base year) by the official CPI figures to generate real earnings.

- Full-time job: The full- versus part-time status of a job is described by a dummy variable taking 1 if it is a full-time job and 0 otherwise. 
- Firm-size: In the survey, firm-size is measured with the number of workers employed in the firm in which the worker is currently employed. This is a categorical variable describing firm size in 6 categories: 1-9, 10-24, 25-49, 50-249, 250-499, and 500 or above. Each category is included as a separate dummy variable into the regressions.

- Industry: The survey provides information on two-digit industry codes based on the standard Nace-Rev2 classification. There are 87 industry categories in our sample. These industry categories are also included into the regressions as separate dummy variables. 


\section{B Description of NUTS2 Regional Classification}

\begin{tabular}{|c|c|c|c|}
\hline Region \# & Region Name & Cities Included & Treatment Status \\
\hline 1 & Istanbul & Istanbul & - \\
\hline 2 & Tekirdag & Tekirdag, Edirne, Kirklareli & - \\
\hline 3 & Balikesir & Balikesir, Canakkale & - \\
\hline 4 & Izmir & Izmir & - \\
\hline 5 & Aydin & Aydin, Denizli, Mugla & - \\
\hline 6 & Manisa & Manisa, Afyonkarahisar, Kutahya, Usak & - \\
\hline 7 & Bursa & Bursa, Eskisehir, Bilecik & - \\
\hline 8 & Kocaeli & Kocaeli, Sakarya, Duzce, Bolu, Yalova & - \\
\hline 9 & Ankara & Ankara & - \\
\hline 10 & Konya & Konya, Karaman & - \\
\hline 11 & Antalya & Antalya, Isparta, Burdur & - \\
\hline 12 & Adana & Adana, Mersin & $\mathrm{T}$ \\
\hline 13 & Hatay & Hatay, Kahramanmaras, Osmaniye & $\mathrm{T}$ \\
\hline 14 & Kirikkale & Kirikkale, Nevsehir, Aksaray, Nigde, Kirsehir & - \\
\hline 15 & Kayseri & Kayseri, Sivas, Yozgat & - \\
\hline 16 & Zonguldak & Zonguldak, Karabuk, Bartin & - \\
\hline 17 & Kastamonu & Kastamonu, Cankiri, Sinop & - \\
\hline 18 & Samsun & Samsun, Tokat, Corum, Amasya & - \\
\hline 19 & Trabzon & Trabzon, Ordu, Giresun, Rize, Artvin, Gumushane & - \\
\hline 20 & Erzurum & Erzurum, Erzincan, Bayburt & $\mathrm{C}$ \\
\hline 21 & Agri & Agri, Kars, Igdir, Ardahan & $\mathrm{C}$ \\
\hline 22 & Malatya & Malatya, Elazig, Bingol, Tunceli & $\mathrm{C}$ \\
\hline 23 & Van & Van, Mus, Bitlis, Hakkari & $\mathrm{C}$ \\
\hline 24 & Gaziantep & Gaziantep, Adiyaman, Kilis & $\mathrm{T}$ \\
\hline 25 & Sanliurfa & Sanliurfa, Diyarbakir & $\mathrm{T}$ \\
\hline 26 & Mardin & Mardin, Siirt, Batman, Sirnak & $\mathrm{T}$ \\
\hline
\end{tabular}

Table A: NUTS2-level Regional Division in Turkey. T: Treatment, C: Control. 


\section{References}

AFAD (2013): "Syrian Refugees in Turkey, 2013: Field Survey Results," Turkish Disaster and Emergency Management Presidency.

Altonji, J. G. And D. CARD (1991): "The Effects of Immigration on the Labor Market Outcomes of Less-Skilled Natives," in Immigration, Trade, and the Labor Market, ed. by J. Abowd and R. B. Freeman, University of Chicago Press, 201-234.

Angrist, J. D. And Kugler (2003): "Protective or Counter-Productive? Labour Market Institutions and the Effect of Immigration on EU Natives," Economic Journal, 113, F302F331.

Angrist, J. D. And J.-S. PischKe (2008): Mostly Harmless Econometrics: An Empiricist's Companion, Princeton, NJ: Princeton University Press.

Aydemir, A. And M. G. KIRdar (2013): "Quasi-Experimental Impact Estimates of Immigrant Labor Supply Shocks: The Role of Treatment and Comparison Group Matching and Relative Skill Composition," IZA Discussion Paper \#7161.

BorJas, G. J. (1987): "Self-Selection and the Earnings of Immigrants," American Economic Review, 77, 531-553.

- (1991): "Immigration and Self Selection," in Immigration, Trade, and the Labor Market, ed. by J. Abowd and R. B. Freeman, Cambridge, MA: National Bureau of Economic Research.

(1994): "The Economics of Immigration," Journal of Economic Literature, 32, 16671717.

(2003): "The Labor Demand Curve is Downward Sloping: Reexamining the Impact of Immigration on the Labor Market," Quarterly Journal of Economics, 118, 1335-1374.

Borjas, G. J., R. B. Freeman, And L. F. Katz (1996): "Searching for the Effect of Immigration on the Labor Market," American Economic Review, 86, 246-251. 
BorJas, G. J. And L. F. Katz (2007): "The Evolution of the Mexican-Born Workforce in the United States," in Mexican Immigration to the United States, ed. by G. J. Borjas, Cambridge, MA: National Bureau of Economic Research.

CARD, D. (1990): "The Impact of the Mariel Boatlift on the Miami Labor Market," Industrial and Labor Relations Review, 43, 245-257.

_ (2001): "Immigrant Inflows, Native Outflows, and the Local Labor Market Impacts of Higher Immigration," Journal of Labor Economics, 19, 22-64.

_ (2009): "Immigration and Inequality," American Economic Review, 99, 1-21.

Card, D. and A. B. Krueger (1994): "Minimum Wages and Employment: A Case Study of the Fast-Food Industry in New Jersey and Pennsylvania," American Economic Review, 84, 772-793.

Carpenter, C. (2004): "How Do Zero Tolerance Drunk Driving Laws Work?" Journal of Health Economics, 23, 61-83.

Carrington, W. J. and P. J. F. De Lima (1996): "The Impact of 1970s Repatriates from Africa on the Portuguese Labor Market," Industrial and Labor Relations Review, 49, $330-347$.

Cohen-Goldner, S. And D. M. Paserman (2011): "The Dynamic Impact of Immigration on Natives' Labor Market Outcomes: Evidence from Israel," European Economic Review, $55,1027-1045$.

Friedberg, R. M. (2000): "You Can't Take It with You? Immigrant Assimilation and the Portability of Human Capital," Journal of Labor Economics, 18, 221-251.

(2001): "The Impact of Mass Migration on the Israeli Labor Market," Quarterly Journal of Economics, 116, 1373-1408.

Friedberg, R. M. And J. Hunt (1995): "The Impact of Immigrants on Host Country Wages, Employment, and Growth," Journal of Economic Perspectives, 9, 23-44. 
GLitz, A. (2012): "The Labor Market Impact of Immigration: A Quasi-Experiment Exploiting Immigrant Location Rules in Germany," Journal of Labor Economics, 30, 175-213.

Goldin, C. (1994): "The Political Economy of Immigration Restriction in the United States, 1890-1921," in The Regulated Economy: A Historical Approach to Political Economy, ed. by C. Goldin and G. Libecap, University of Chicago Press, 223-257.

Hunt, J. (1992): "The Impact of the 1962 Repatriates from Algeria on the French Labor Market," Industrial and Labor Relations Review, 43, 556-572.

LaLonde, R. J. and R. H. Topel (1997): "Economic Impact of International Migration and the Economic Performance of Migrants," in Handbook of Population and Family Economics, ed. by M. R. Rosenzweig and O. Stark, Amsterdam: Elsevier, 799-850.

Lavy, V. (2010): "Effects of Free Choice among Public Schools," Review of Economic Studies, $77,1164-1191$.

Mansour, H. (2010): "The Effects of Labor Supply Shocks on Labor Market Outcomes: Evidence from the Israeli-Palestinian Conflict," Labour Economics, 17, 930-939.

Maystadt, J.-F. And P. Verwimp (2014): "Winners and Losers among a Refugee-Hosting Population," Economic Development and Cultural Change, 62, 769-809.

Ottaviano, G. I. P. And G. Peri (2011): "Rethinking the Effect of Immigration on Wages," Journal of the European Economic Association, 10, 152-197.

PischKe, J.-S. And J. Velling (1997): "Employment Effects of Immigration to Germany: An Analysis Based on Local Labor Markets," Review of Economics and Statistics, 79, 594604 .

Pissarides, C. A. (2009): "The Unemployment Volatility Puzzle: Is Wage Stickiness the Answer?" Econometrica, 77, 1339-1369.

Weiss, Y., R. M. Sauer, and M. Gotlibovski (2003): "Immigration, Search, and Loss of Skill," Journal of Labor Economics, 21, 557-591. 
Wooldridge, J. M. (2010): Econometric Analysis of Cross Section and Panel Data, Cambridge, MA: Cambridge University Press, 2nd ed. 


\begin{tabular}{lccccc}
\hline \hline \multicolumn{5}{c}{ Treatment } & Area \\
\hline & Pre-treatment & Post-treatment \\
\hline Male & $\mathbf{2 0 1 0}$ & $\mathbf{2 0 1 1}$ & $\mathbf{2 0 1 2}$ & $\mathbf{2 0 1 3}$ & Total \\
Age & 0.481 & 0.482 & 0.480 & 0.480 & 0.481 \\
Married & 34.6 & 34.9 & 35.2 & 35.5 & 35.0 \\
High school and above & 0.645 & 0.640 & 0.635 & 0.638 & 0.640 \\
Urban & 0.221 & 0.233 & 0.236 & 0.247 & 0.234 \\
\# of observations & 0.729 & 0.743 & 0.740 & 0.752 & 0.741 \\
\hline \hline & 58,143 & 56,382 & 56,167 & 54,656 & 225,348 \\
\hline \multicolumn{5}{c}{ Control Area } & \\
\hline \multirow{5}{*}{ Male } & Pre-treatment & Post-treatment & \\
Age & $\mathbf{2 0 1 0}$ & $\mathbf{2 0 1 1}$ & $\mathbf{2 0 1 2}$ & $\mathbf{2 0 1 3}$ & Total \\
Married & 0.479 & 0.489 & 0.491 & 0.490 & 0.487 \\
High school and above & 34.0 & 34.1 & 34.4 & 34.5 & 34.2 \\
Urban & 0.216 & 0.232 & 0.261 & 0.248 & 0.239 \\
\# of observations & 0.532 & 0.509 & 0.512 & 0.525 & 0.520 \\
\hline \hline
\end{tabular}

Table 3: Summary Statistics: Demographic Characteristics for Natives. The table reports the mean values for the corresponding individual-level characteristic. 


\begin{tabular}{|c|c|c|c|c|c|}
\hline & \multicolumn{5}{|c|}{ Treatment Area } \\
\hline & \multicolumn{2}{|c|}{ Pre-treatment } & \multicolumn{2}{|c|}{ Post-treatment } & \multirow[b]{2}{*}{ Total } \\
\hline & 2010 & 2011 & 2012 & 2013 & \\
\hline $\mathrm{TE} / \mathrm{P}$ & 0.388 & 0.397 & 0.387 & 0.396 & 0.392 \\
\hline $\mathrm{FE} / \mathrm{P}$ & 0.166 & 0.182 & 0.195 & 0.215 & 0.189 \\
\hline $\mathrm{IE} / \mathrm{P}$ & 0.222 & 0.215 & 0.192 & 0.181 & 0.203 \\
\hline $\mathrm{U} / \mathrm{P}$ & 0.066 & 0.054 & 0.050 & 0.061 & 0.058 \\
\hline LFP & 0.454 & 0.451 & 0.437 & 0.457 & 0.450 \\
\hline Real wages (TL) & 871.5 & 897.9 & 950.0 & 962.1 & 921.5 \\
\hline Separation prob. & 0.087 & 0.076 & 0.076 & 0.102 & 0.085 \\
\hline \multirow[t]{4}{*}{ Job finding prob. } & 0.385 & 0.434 & 0.417 & 0.398 & 0.408 \\
\hline & \multicolumn{5}{|c|}{ Control Area } \\
\hline & \multicolumn{2}{|c|}{ Pre-treatment } & \multicolumn{2}{|c|}{ Post-treatment } & \\
\hline & 2010 & 2011 & 2012 & 2013 & Total \\
\hline $\mathrm{TE} / \mathrm{P}$ & 0.439 & 0.457 & 0.462 & 0.476 & 0.458 \\
\hline $\mathrm{FE} / \mathrm{P}$ & 0.158 & 0.180 & 0.198 & 0.200 & 0.183 \\
\hline $\mathrm{IE} / \mathrm{P}$ & 0.281 & 0.277 & 0.264 & 0.275 & 0.275 \\
\hline $\mathrm{U} / \mathrm{P}$ & 0.057 & 0.050 & 0.041 & 0.043 & 0.048 \\
\hline LFP & 0.496 & 0.507 & 0.502 & 0.519 & 0.506 \\
\hline Real wages & 1072.0 & 1077.5 & 1133.0 & 1103.3 & 1097.3 \\
\hline Separation prob. & 0.052 & 0.054 & 0.059 & 0.062 & 0.057 \\
\hline Job finding prob. & 0.331 & 0.385 & 0.409 & 0.407 & 0.381 \\
\hline
\end{tabular}

Table 4: Summary Statistics: Labor Market Outcomes for Natives. The table reports the mean values for the corresponding labor market outcome. The real wage variable is defined as monthly real wages in Turkish Liras (TL). 2010 is taken as the base year in calculating real wages. TE/P: Total employment over population, FE/P: Formal employment over population, IE/P: Informal employment over population, U/P: Unemployment over population, and LFP: Labor force over population. 

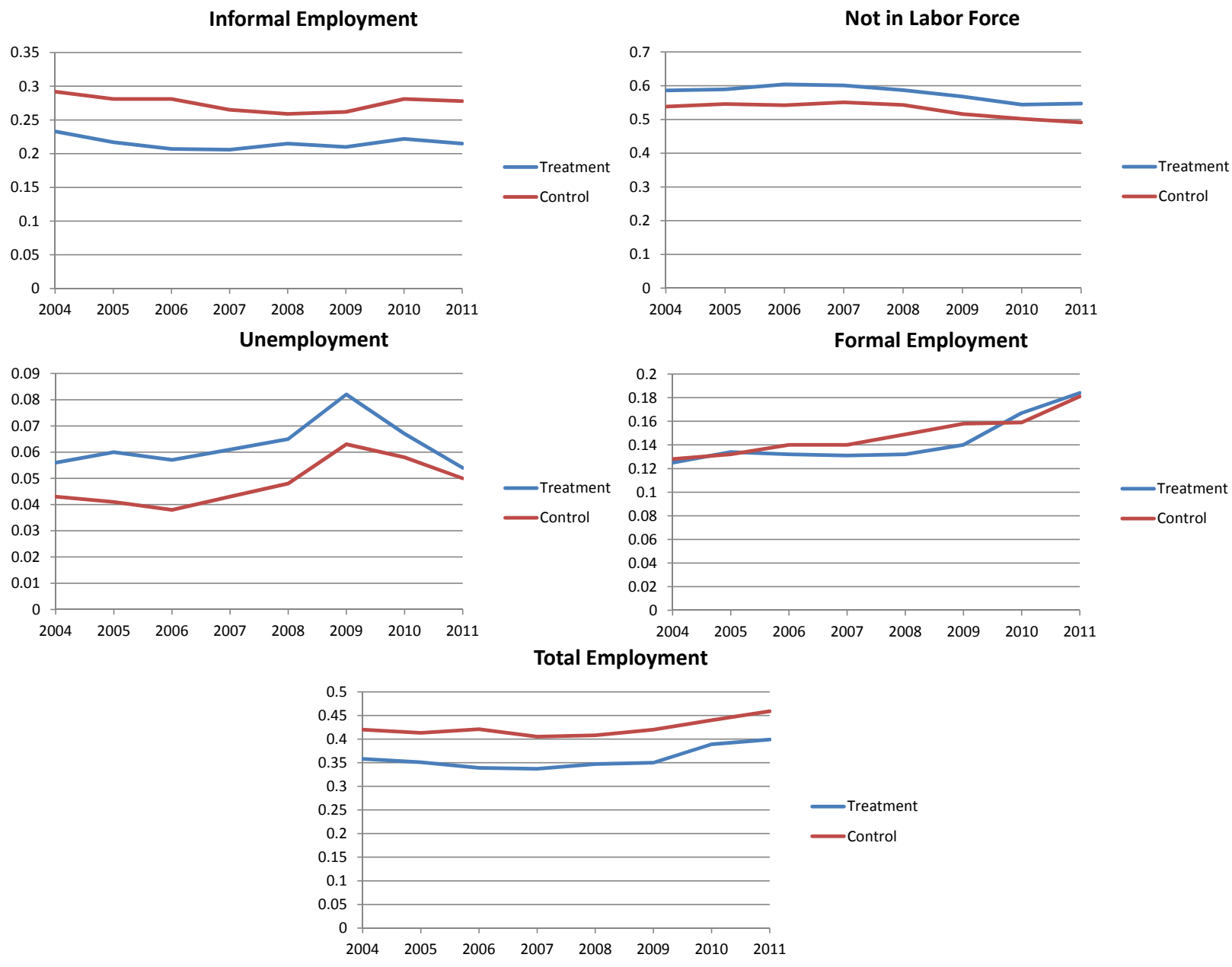

Figure 3: Prior trends in treatment versus control areas. The figures above compare the trends in the labor market outcomes in treatment versus control areas prior to immigration (i.e., between 2004-2011). Note that all variables are characterized in terms of their ratios to the population of native individuals of age 15-64. For example, the unemployment rate should be read as the ratio of unemployed individuals to the population of individuals aged 15-64. The figures suggest that the prior trends are quite similar across treatment and control areas. 
Informal employment-to-population ratio

\begin{tabular}{l|c|c|c|c|c|c}
\hline \hline Variable & Total & Total & Male & Female & Low Ed. & High Ed. \\
\hline Refugee effect $(R \times T)$ & $-0.0226^{* * *}$ & $-0.0223^{* * *}$ & $-0.0190^{* * *}$ & $-0.0260^{* * *}$ & $-0.0335^{* * *}$ & 0.0071 \\
& $(0.0028)$ & $(0.0028)$ & $(0.0044)$ & $(0.0034)$ & $(0.0033)$ & $(0.0045)$ \\
Log trade vol. & No & Yes & Yes & Yes & Yes & Yes \\
Year fixed effects & Yes & Yes & Yes & Yes & Yes & Yes \\
Region fixed effects & Yes & Yes & Yes & Yes & Yes & Yes \\
Other Controls & Yes & Yes & Yes & Yes & Yes & Yes \\
Intercept & $0.1904^{* * *}$ & $0.4872^{* * *}$ & $0.9640^{* * *}$ & 0.2376 & $0.5985^{* * *}$ & -0.1571 \\
& $(0.0079)$ & $(0.1289)$ & $(0.2074)$ & $(0.1529)$ & $(0.1548)$ & $(0.2173)$ \\
\hline$R^{2}$ & 0.139 & 0.139 & 0.119 & 0.129 & 0.137 & 0.077 \\
$\#$ of Obs. & 357,083 & 357,083 & 172,385 & 184,698 & 273,453 & 83,630 \\
\hline Sample means & 0.2287 & 0.2287 & 0.3119 & 0.1511 & 0.2617 & 0.1211 \\
\hline \hline
\end{tabular}

Table 5: Informal Employment-to-population ratio. ***, **, and * refer to 1\%, 5\%, and $10 \%$ significance levels, respectively. Robust standard errors are reported in parentheses. Sample is restricted to the age group 15-64. Controls include: gender, marital status, age dummies, education dummies, a full set of age-education interactions, and urban versus rural area dummy. High education refers to high-school degree and above. Low education refers to high school dropouts and below. 
Labor Force Participation

\begin{tabular}{l|c|c|c|c|c|c}
\hline \hline Variable & Total & Total & Male & Female & Low Ed. & High Ed. \\
\hline Refugee effect $(R \times T)$ & $-0.0103^{* * *}$ & $-0.0110^{* * *}$ & 0.0038 & $-0.0257^{* * *}$ & $-0.0167^{* * *}$ & 0.0029 \\
& $(0.0028)$ & $(0.0028)$ & $(0.0037)$ & $(0.0039)$ & $(0.0032)$ & $(0.0055)$ \\
Log trade vol. & No & Yes & Yes & Yes & Yes & Yes \\
Year fixed effects & Yes & Yes & Yes & Yes & Yes & Yes \\
Region fixed effects & Yes & Yes & Yes & Yes & Yes & Yes \\
Other Controls & Yes & Yes & Yes & Yes & Yes & Yes \\
Intercept & $0.0598^{* * *}$ & $-0.6250^{* * *}$ & $-0.8098^{* * *}$ & -0.0516 & $-0.4138^{* * *}$ & $-1.6204^{* * *}$ \\
& $(0.0087)$ & $(0.1306)$ & $(0.1822)$ & $(0.1739)$ & $(0.1489)$ & $(0.2972)$ \\
\hline$R^{2}$ & 0.380 & 0.380 & 0.310 & 0.180 & 0.369 & 0.348 \\
$\#$ of Obs. & 357,083 & 357,083 & 172,385 & 184,698 & 273,453 & 83,630 \\
\hline Sample means & 0.4700 & 0.4700 & 0.7212 & 0.2356 & 0.4193 & 0.6360 \\
\hline \hline
\end{tabular}

Table 6: Labor Force Participation. ***, **, and * refer to 1\%, 5\%, and 10\% significance levels, respectively. Robust standard errors are reported in parentheses. Sample is restricted to the age group 15-64. Controls include: gender, marital status, age dummies, education dummies, a full set of age-education interactions, and urban versus rural area dummy. High education refers to high-school degree and above. Low education refers to high school dropouts and below. 
Unemployment-to-population ratio

\begin{tabular}{l|c|c|c|c|c|c}
\hline \hline Variable & Total & Total & Male & Female & Low Ed. & High Ed. \\
\hline Refugee effect $(R \times T)$ & $0.0077^{* * *}$ & $0.0070^{* * *}$ & $0.0138^{* * *}$ & 0.0007 & $0.0072^{* * *}$ & 0.0054 \\
& $(0.0015)$ & $(0.0015)$ & $(0.0027)$ & $(0.0014)$ & $(0.0016)$ & $(0.0037)$ \\
Log trade vol. & No & Yes & Yes & Yes & Yes & Yes \\
Year fixed effects & Yes & Yes & Yes & Yes & Yes & Yes \\
Region fixed effects & Yes & Yes & Yes & Yes & Yes & Yes \\
Other Controls & Yes & Yes & Yes & Yes & Yes & Yes \\
Intercept & $0.0069^{* *}$ & $-0.6696^{* * *}$ & $-1.1540^{* * *}$ & $-0.1816^{* * *}$ & $-0.6592^{* * *}$ & $-0.8264^{* * *}$ \\
& $(0.0034)$ & $(0.0683)$ & $(0.1258)$ & $(0.0588)$ & $(0.0729)$ & $(0.1677)$ \\
\hline$R^{2}$ & 0.046 & 0.046 & 0.031 & 0.065 & 0.049 & 0.049 \\
$\#$ of Obs. & 357,083 & 357,083 & 172,385 & 184,698 & 273,453 & 83,630 \\
\hline Sample means & 0.0543 & 0.0543 & 0.0855 & 0.0251 & 0.0471 & 0.0776 \\
\hline \hline
\end{tabular}

Table 7: Unemployment-to-population ratio. ${ }^{* * *},{ }^{* *}$, and $*$ refer to $1 \%, 5 \%$, and $10 \%$ significance levels, respectively. Robust standard errors are reported in parentheses. Sample is restricted to the age group 1564. Controls include: gender, marital status, age dummies, education dummies, a full set of age-education interactions, and urban versus rural area dummy. High education refers to high-school degree and above. Low education refers to high school dropouts and below. 
Formal employment-to-population ratio

\begin{tabular}{l|c|c|c|c|c|c}
\hline \hline Variable & Total & Total & Male & Female & Low Ed. & High Ed. \\
\hline Refugee effect $(R \times T)$ & $0.0046^{* *}$ & $0.0043^{* *}$ & $0.0089^{* *}$ & -0.0004 & $0.0096^{* * *}$ & -0.0096 \\
& $(0.0022)$ & $(0.0022)$ & $(0.0039)$ & $(0.0019)$ & $(0.0022)$ & $(0.0059)$ \\
Log trade vol. & No & Yes & Yes & Yes & Yes & Yes \\
Year fixed effects & Yes & Yes & Yes & Yes & Yes & Yes \\
Region fixed effects & Yes & Yes & Yes & Yes & Yes & Yes \\
Other Controls & Yes & Yes & Yes & Yes & Yes & Yes \\
Intercept & $-0.1376^{* * *}$ & $-0.4426^{* * *}$ & $-0.6199^{* * *}$ & -0.1075 & $-0.3531^{* * *}$ & $-0.6369^{* *}$ \\
& $(0.0031)$ & $(0.1027)$ & $(0.1836)$ & $(0.0855)$ & $(0.1035)$ & $(0.2939)$ \\
\hline$R^{2}$ & 0.348 & 0.348 & 0.311 & 0.336 & 0.203 & 0.327 \\
$\#$ of Obs. & 357,083 & 357,083 & 172,385 & 184,698 & 273,453 & 83,630 \\
\hline Sample means & 0.1871 & 0.1871 & 0.3239 & 0.0594 & 0.1105 & 0.4373 \\
\hline \hline
\end{tabular}

Table 8: Formal Employment-to-population ratio. ${ }^{* * *},{ }^{* *}$, and $*$ refer to $1 \%, 5 \%$, and $10 \%$ significance levels, respectively. Robust standard errors are reported in parentheses. Sample is restricted to the age group 15-64. Controls include: gender, marital status, age dummies, education dummies, a full set of age-education interactions, and urban versus rural area dummy. High education refers to high-school degree and above. Low education refers to high school dropouts and below. 
Job separation probability

\begin{tabular}{l|c|c|c|c|c|c}
\hline \hline Variable & Total & Total & Male & Female & Low Ed. & High Ed. \\
\hline Refugee effect $(R \times T)$ & 0.0012 & 0.0011 & 0.0007 & 0.0030 & 0.0032 & -0.0014 \\
& $(0.0027)$ & $(0.0027)$ & $(0.0031)$ & $(0.0058)$ & $(0.0034)$ & $(0.0046)$ \\
Log trade vol. & No & Yes & Yes & Yes & Yes & Yes \\
Year fixed effects & Yes & Yes & Yes & Yes & Yes & Yes \\
Region fixed effects & Yes & Yes & Yes & Yes & Yes & Yes \\
Other Controls & Yes & Yes & Yes & Yes & Yes & Yes \\
Intercept & $0.1143^{* * *}$ & 0.1011 & 0.0171 & 0.1772 & 0.0908 & -0.3002 \\
& $(0.0193)$ & $(0.1369)$ & $(0.1547)$ & $(0.2860)$ & $(0.1714)$ & $(0.3540)$ \\
\hline$R^{2}$ & 0.031 & 0.031 & 0.025 & 0.070 & 0.027 & 0.046 \\
$\#$ of Obs. & 137,496 & 137,496 & 101,017 & 36,479 & 94,169 & 43,327 \\
\hline Sample means & 0.0736 & 0.0736 & 0.0675 & 0.0906 & 0.0792 & 0.0615 \\
\hline \hline
\end{tabular}

Table 9: Job separation probability. ${ }^{* * *},{ }^{* *}$, and ${ }^{*}$ refer to $1 \%, 5 \%$, and $10 \%$ significance levels, respectively. Robust standard errors are reported in parentheses. Job separation probability is defined as the fraction of currently non-employed workers among those who were employed exactly one year ago. Sample is restricted to the age group 15-64. Controls include: gender, marital status, age dummies, education dummies, a full set of age-education interactions, and urban versus rural area dummy. High education refers to high-school degree and above. Low education refers to high school dropouts and below. 
Job finding probability

\begin{tabular}{l|c|c|c|c|c|c}
\hline \hline Variable & Total & Total & Male & Female & Low Ed. & High Ed. \\
\hline Refugee effect $(R \times T)$ & $-0.0473^{* * *}$ & $-0.0474^{* * *}$ & $-0.0452^{* * *}$ & $-0.0714^{*}$ & $-0.0666^{* * *}$ & 0.0119 \\
& $(0.0123)$ & $(0.0123)$ & $(0.0131)$ & $(0.0368)$ & $(0.0143)$ & $(0.0242)$ \\
Log trade vol. & No & Yes & Yes & Yes & Yes & Yes \\
Year fixed effects & Yes & Yes & Yes & Yes & Yes & Yes \\
Region fixed effects & Yes & Yes & Yes & Yes & Yes & Yes \\
Other Controls & Yes & Yes & Yes & Yes & Yes & Yes \\
Intercept & $0.1156^{* * *}$ & 0.0986 & -0.0101 & 2.8531 & -0.1136 & 0.2772 \\
& $(0.0351)$ & $(0.5752)$ & $(0.6050)$ & $(1.9538)$ & $(0.6634)$ & $(1.2260)$ \\
\hline$R^{2}$ & 0.056 & 0.056 & 0.060 & 0.111 & 0.052 & 0.075 \\
$\#$ of Obs. & 29,362 & 29,362 & 25,989 & 3,373 & 21,989 & 7,373 \\
\hline Sample means & 0.3993 & 0.3993 & 0.4093 & 0.3220 & 0.3963 & 0.4083 \\
\hline \hline
\end{tabular}

Table 10: Job finding probability. ${ }^{* * *}{ }^{* *}$, and ${ }^{*}$ refer to $1 \%, 5 \%$, and $10 \%$ significance levels, respectively. Robust standard errors are reported in parentheses. Job finding probability is defined as the fraction of currently employed workers among those who were actively seeking for a job exactly one year ago. Sample is restricted to the age group 15-64. Controls include: gender, marital status, age dummies, education dummies, a full set of age-education interactions, and urban versus rural area dummy. High education refers to highschool degree and above. Low education refers to high school dropouts and below. 
Refugee effects by age groups

\begin{tabular}{l|c|c|c|c|c|c}
\hline \hline Outcome & $\mathbf{1 5 - 2 4}$ & $\mathbf{2 5 - 3 4}$ & $\mathbf{3 5 - 4 4}$ & $\mathbf{4 5 - 5 4}$ & $\mathbf{5 5 - 6 4}$ & Total \\
\hline LFP & -0.0069 & $-0.0224^{* * *}$ & $-0.0095^{*}$ & -0.0077 & -0.0097 & $-0.0110^{* * *}$ \\
& $(0.0053)$ & $(0.0054)$ & $(0.0057)$ & $(0.0070)$ & $(0.0090)$ & $(0.0028)$ \\
U/P & $0.0121^{* * *}$ & $0.0142^{* * *}$ & 0.0043 & -0.0044 & 0.0002 & $0.0070^{* * *}$ \\
& $(0.0029)$ & $(0.0037)$ & $(0.0033)$ & $(0.0032)$ & $(0.0026)$ & $(0.0015)$ \\
IE/P & $-0.0206^{* * *}$ & $-0.0263^{* * *}$ & $-0.0273^{* * *}$ & -0.0092 & $-0.0263^{* * *}$ & $-0.0223^{* * *}$ \\
& $(0.0048)$ & $(0.0057)$ & $(0.0064)$ & $(0.0074)$ & $(0.0086)$ & $(0.0028)$ \\
FE/P & 0.0026 & $-0.0103^{* *}$ & $0.0135^{* *}$ & 0.0059 & $0.0164^{* * *}$ & $0.0043^{* *}$ \\
& $(0.0029)$ & $(0.0052)$ & $(0.0053)$ & $(0.0060)$ & $(0.0057)$ & $(0.0022)$ \\
SP & -0.0014 & 0.0042 & 0.0040 & -0.0028 & 0.0046 & 0.0011 \\
& $(0.0082)$ & $(0.0053)$ & $(0.0045)$ & $(0.0056)$ & $(0.0085)$ & $(0.0027)$ \\
JFP & $-0.0720^{* * *}$ & -0.0292 & -0.0181 & -0.0457 & $-0.1043^{*}$ & $-0.0474^{* * *}$ \\
& $(0.0208)$ & $(0.0220)$ & $(0.0288)$ & $(0.0367)$ & $(0.0596)$ & $(0.0123)$ \\
\hline \hline
\end{tabular}

Table 11: Refugee effects by age groups. ${ }^{* *},{ }^{* *}$, and ${ }^{*}$ refer to $1 \%, 5 \%$, and $10 \%$ significance levels, respectively. Robust standard errors are reported in parentheses. 
Informal Real Monthly Earnings (Natural Logs)

\begin{tabular}{l|c|c|c|c|c|c}
\hline \hline Variable & Total & Total & Male & Female & Low Ed. & High Ed. \\
\hline Refugee effect $(R \times T)$ & -0.0123 & -0.0094 & -0.0126 & -0.0405 & -0.0097 & 0.0005 \\
& $(0.0119)$ & $(0.0119)$ & $(0.0127)$ & $(0.0370)$ & $(0.0131)$ & $(0.0294)$ \\
Log trade vol. & No & Yes & Yes & Yes & Yes & Yes \\
Year fixed effects & Yes & Yes & Yes & Yes & Yes & Yes \\
Region fixed effects & Yes & Yes & Yes & Yes & Yes & Yes \\
Other Controls & Yes & Yes & Yes & Yes & Yes & Yes \\
Intercept & $5.0709^{* * *}$ & $6.2261^{* * *}$ & $5.9523^{* * *}$ & $6.0629^{* * *}$ & $6.1896^{* * *}$ & $7.0521^{* * *}$ \\
& $(0.0503)$ & $(0.5779)$ & $(0.6088)$ & $(1.7104)$ & $(0.6320)$ & $(1.4356)$ \\
\hline$R^{2}$ & 0.350 & 0.350 & 0.334 & 0.379 & 0.355 & 0.359 \\
$\#$ of Obs. & 26,033 & 26,033 & 21,366 & 4,667 & 21,848 & 4,185 \\
\hline Sample means & 6.0905 & 6.0905 & 6.1489 & 5.8470 & 6.0688 & 6.2056 \\
\hline \hline
\end{tabular}

Table 12: Informal Real Monthly Earnings. ${ }^{* * *},{ }^{* *}$, and ${ }^{*}$ refer to $1 \%, 5 \%$, and $10 \%$ significance levels, respectively. Robust standard errors are reported in parentheses. Real wages are deflated with the CPI taking 2010 as the base year. Sample is restricted to the age group 15-64. Controls include: gender, marital status, age dummies, education dummies, a full set of age-education interactions, full-time vs part-time job status dummy, firm size dummies, urban versus rural area dummy, and industry dummies. High education refers to high-school degree and above. Low education refers to high school dropouts and below. The sample includes the salaried workers only. 
Formal Real Monthly Earnings (Natural Logs)

\begin{tabular}{l|c|c|c|c|c|c}
\hline \hline Variable & Total & Total & Male & Female & Low Ed. & High Ed. \\
\hline Refugee effect $(R \times T)$ & 0.0081 & 0.0081 & 0.0081 & 0.0182 & -0.0009 & $0.0155^{*}$ \\
& $(0.0064)$ & $(0.0064)$ & $(0.0070)$ & $(0.0151)$ & $(0.0105)$ & $(0.0079)$ \\
Log trade vol. & No & Yes & Yes & Yes & Yes & Yes \\
Year fixed effects & Yes & Yes & Yes & Yes & Yes & Yes \\
Region fixed effects & Yes & Yes & Yes & Yes & Yes & Yes \\
Other Controls & Yes & Yes & Yes & Yes & Yes & Yes \\
Intercept & $5.8299^{* * *}$ & $5.6346^{* * *}$ & $5.5176^{* * *}$ & $5.8832^{* * *}$ & $4.8229^{* * *}$ & $5.7165^{* * *}$ \\
& $(0.1359)$ & $(0.3293)$ & $(0.3581)$ & $(0.7940)$ & $(0.4979)$ & $(0.4603)$ \\
\hline$R^{2}$ & 0.618 & 0.618 & 0.614 & 0.664 & 0.380 & 0.593 \\
$\#$ of Obs. & 52,701 & 52,701 & 42,942 & 9,759 & 20,616 & 32,085 \\
\hline Sample means & 6.8609 & 6.8609 & 6.8524 & 6.9005 & 6.5706 & 7.0663 \\
\hline \hline
\end{tabular}

Table 13: Formal Real Monthly Earnings. ***, **, and * refer to $1 \%, 5 \%$, and $10 \%$ significance levels, respectively. Robust standard errors are reported in parentheses. Real wages are deflated with the CPI taking 2010 as the base year. Sample is restricted to the age group 15-64. Controls include: gender, marital status, age dummies, education dummies, a full set of age-education interactions, full-time vs part-time job status dummy, firm size dummies, urban versus rural area dummy, and industry dummies. High education refers to high-school degree and above. Low education refers to high school dropouts and below. The sample includes the salaried workers only. 
Robustness Exercise: Treatment Area vs Randomly Selected Control Areas

\begin{tabular}{|c|c|c|c|c|}
\hline \multicolumn{5}{|c|}{ Refugee effects $(R \times T)$ are reported only. } \\
\hline $\begin{array}{l}\text { Region Combinations } \\
\text { (Control Area) }\end{array}$ & IE/P & LFP & $\mathbf{U} / \mathbf{P}$ & FE/P \\
\hline Alternative control area $[\mathbf{1}]$ & $\begin{array}{c}-0.0216^{* * *} \\
(0.0025)\end{array}$ & $\begin{array}{c}-0.0186^{* * *} \\
(0.0023)\end{array}$ & $\begin{array}{c}0.0007 \\
(0.0014)\end{array}$ & $\begin{array}{l}-0.0037^{*} \\
(0.0022)\end{array}$ \\
\hline Alternative control area [2] & $\begin{array}{c}-0.0321^{* * *} \\
(0.0025)\end{array}$ & $\begin{array}{c}-0.0266^{* * *} \\
(0.0023)\end{array}$ & $\begin{array}{c}-0.0040^{* * *} \\
(0.0015)\end{array}$ & $\begin{array}{l}-0.0016 \\
(0.0022)\end{array}$ \\
\hline Alternative control area $[\mathbf{3}]$ & $\begin{array}{c}-0.0392^{* * *} \\
(0.0029)\end{array}$ & $\begin{array}{c}-0.0432^{* * *} \\
(0.0028)\end{array}$ & $\begin{array}{c}0.0034^{* *} \\
(0.0016)\end{array}$ & $\begin{array}{c}0.0007 \\
(0.0026)\end{array}$ \\
\hline Alternative control area $[4]$ & $\begin{array}{c}-0.0243^{* * *} \\
(0.0026)\end{array}$ & $\begin{array}{c}-0.0277^{* * *} \\
(0.0024)\end{array}$ & $\begin{array}{c}-0.0034^{* *} \\
(0.0015)\end{array}$ & $\begin{array}{c}0.0068^{* * *} \\
(0.0023)\end{array}$ \\
\hline Alternative control area $[5]$ & $\begin{array}{c}-0.0163^{* * *} \\
(0.0026)\end{array}$ & $\begin{array}{c}-0.0120^{* * *} \\
(0.0025)\end{array}$ & $\begin{array}{l}-0.0009 \\
(0.0014)\end{array}$ & $\begin{array}{l}-0.0035 \\
(0.0023)\end{array}$ \\
\hline Alternative control area $[\mathbf{6}]$ & $\begin{array}{c}-0.0181^{* * *} \\
(0.0027)\end{array}$ & $\begin{array}{c}-0.0168^{* * *} \\
(0.0025)\end{array}$ & $\begin{array}{c}0.0043^{* * *} \\
(0.0015)\end{array}$ & $\begin{array}{c}-0.0057^{* *} \\
(0.0024)\end{array}$ \\
\hline Alternative control area [7] & $\begin{array}{c}-0.0264^{* * *} \\
(0.0023)\end{array}$ & $\begin{array}{c}-0.0222^{* * *} \\
(0.0021)\end{array}$ & $\begin{array}{c}-0.0047^{* * *} \\
(0.0013)\end{array}$ & $\begin{array}{c}0.0005 \\
(0.0020)\end{array}$ \\
\hline Alternative control area $[8]$ & $\begin{array}{c}-0.0310^{* * *} \\
(0.0025)\end{array}$ & $\begin{array}{c}-0.0299^{* * *} \\
(0.0023)\end{array}$ & $\begin{array}{l}-0.0017 \\
(0.0015)\end{array}$ & $\begin{array}{c}0.0006 \\
(0.0022)\end{array}$ \\
\hline Alternative control area [9] & $\begin{array}{c}-0.0161^{* * *} \\
(0.0028)\end{array}$ & $\begin{array}{c}-0.0245^{* * *} \\
(0.0027)\end{array}$ & $\begin{array}{c}0.0102^{* * *} \\
(0.0016)\end{array}$ & $\begin{array}{l}-0.0018 \\
(0.0025)\end{array}$ \\
\hline Alternative control area [10] & $\begin{array}{l}-0.0031 \\
(0.0027)\end{array}$ & $\begin{array}{c}-0.0060 * * \\
(0.0026)\end{array}$ & $\begin{array}{l}0.0024^{*} \\
(0.0014)\end{array}$ & $\begin{array}{c}0.0005 \\
(0.0023)\end{array}$ \\
\hline Alternative control area $[\mathbf{1 1}]$ & $\begin{array}{c}-0.0218^{* * *} \\
(0.0024)\end{array}$ & $\begin{array}{c}-0.0247^{* * *} \\
(0.0022)\end{array}$ & $\begin{array}{c}0.0028^{* *} \\
(0.0014)\end{array}$ & $\begin{array}{c}0.0001 \\
(0.0022)\end{array}$ \\
\hline Alternative control area [12] & $\begin{array}{c}-0.0264^{* * *} \\
(0.0024)\end{array}$ & $\begin{array}{c}-0.0173^{* * *} \\
(0.0022)\end{array}$ & $\begin{array}{c}-0.0051^{* * *} \\
(0.0013)\end{array}$ & $\begin{array}{l}-0.0040^{*} \\
(0.0022)\end{array}$ \\
\hline Log trade vol. & Yes & Yes & Yes & Yes \\
\hline Year fixed effects & Yes & Yes & Yes & Yes \\
\hline Region fixed effects & Yes & Yes & Yes & Yes \\
\hline Other Controls & Yes & Yes & Yes & Yes \\
\hline
\end{tabular}

Table 14: Robustness Exercise II. ${ }^{* * *},{ }^{* *}$, and ${ }^{*}$ refer to $1 \%, 5 \%$, and $10 \%$ significance levels, respectively. Robust standard errors are reported in parentheses. Sample is restricted to the age group 15-64. Controls include: gender, marital status, age dummies, education dummies, a full set of age-education interactions, region dummies, year dummies, log trade volumes, and urban versus rural area dummy. This exercise fixes the treatment area and compares it with 12 randomly selected combinations of control areas (excluding the original control area). Based on the NUTS2 region classification in Turkey, the alternative control areas are formed as combinations of 4 NUTS2 regions as follows: [1] 6, 9, 11, 17; [2] 4, 7, 14, 15; [3] 5, 6, 11, 16; [4] 4, $5,16,18 ;[\mathbf{5}] 2,8,14,19 ;[\mathbf{6}] 7,15,16,17 ;[\mathbf{7}] 3,4,7,9 ;[\mathbf{8}] 4,5,8,11 ;[\mathbf{9}] 5,11,15,17 ;[\mathbf{1 0}] 2,5,17,19 ;[\mathbf{1 1}]$ $2,3,5,9 ;[\mathbf{1 2}] 6,7,9,19$. See Appendix B for the details of NUTS2-level regional division in Turkey. 
Robustness Exercise: (pre vs 2012) and (pre vs 2013)

\begin{tabular}{l|c|c||c|c}
\hline \hline Variable & U/P (2012) & U/P (2013) & LFP (2012) & LFP (2013) \\
\hline Refugee effect $(R \times T)$ & $0.0032^{*}$ & $0.0122^{* * *}$ & $-0.0085^{* *}$ & $-0.0122^{* * *}$ \\
& $(0.0018)$ & $(0.0019)$ & $(0.0034)$ & $(0.0034)$ \\
Year fixed effects & Yes & Yes & Yes & Yes \\
Region fixed effects & Yes & Yes & Yes & Yes \\
Other Controls & Yes & Yes & Yes & Yes \\
Intercept & 0.0043 & $0.0068^{*}$ & $0.0414^{* * *}$ & $0.0643^{* * *}$ \\
& $(0.0035)$ & $(0.0039)$ & $(0.0092)$ & $(0.0101)$ \\
\hline$R^{2}$ & 0.047 & 0.047 & 0.385 & 0.379 \\
$\#$ of Obs. & 270,357 & 269,051 & 270,357 & 269,051 \\
\hline \hline Variable & IE/P (2012) & IE/P (2013) & F/P (2012) & F/P (2013) \\
\hline Refugee effect $(R \times T)$ & $-0.0130^{* * *}$ & $-0.0324^{* * *}$ & 0.0013 & $0.0080^{* * *}$ \\
& $(0.0034)$ & $(0.0034)$ & $(0.0027)$ & $(0.0027)$ \\
Year fixed effects & Yes & Yes & Yes & Yes \\
Region fixed effects & Yes & Yes & Yes & Yes \\
Other Controls & Yes & Yes & Yes & Yes \\
Intercept & $0.1713^{* * *}$ & $0.1872^{* * *}$ & $-0.1343^{* * *}$ & $-0.1298^{* * *}$ \\
& $(0.0082)$ & $(0.0092)$ & $(0.0032)$ & $(0.0036)$ \\
\hline$R^{2}$ & 0.143 & 0.139 & 0.346 & 0.346 \\
$\#$ of Obs. & 270,357 & 269,051 & 270,357 & 269,051 \\
\hline \hline
\end{tabular}

Table 15: Robustness Exercise I. ${ }^{* * *},{ }^{* *}$, and $*$ refer to $1 \%, 5 \%$, and $10 \%$ significance levels, respectively. Robust standard errors are reported in parentheses. Sample is restricted to the age group 15-64. Controls include: gender, marital status, age dummies, education dummies, a full set of age-education interactions, log trade volume, and urban versus rural area dummy. High education refers to high-school degree and above. Low education refers to high school dropouts and below. 